\title{
Idiosyncratic volatility and the pricing of poorly-diversified portfolios
}

Article

Accepted Version

Miffre, J., Brooks, C. and Li, X. (2013) Idiosyncratic volatility and the pricing of poorly-diversified portfolios. International Review of Financial Analysis, 30. pp. 78-85. ISSN 1057-5219 doi: https://doi.org/10.1016/j.irfa.2013.05.007 Available at https://centaur.reading.ac.uk/36098/

It is advisable to refer to the publisher's version if you intend to cite from the work. See Guidance on citing.

To link to this article DOI: http://dx.doi.org/10.1016/j.irfa.2013.05.007

Publisher: Elsevier

All outputs in CentAUR are protected by Intellectual Property Rights law, including copyright law. Copyright and IPR is retained by the creators or other copyright holders. Terms and conditions for use of this material are defined in the End User Agreement.

\section{www.reading.ac.uk/centaur}

\section{CentAUR}

Central Archive at the University of Reading

Reading's research outputs online 
NOTICE: this is the author's version of a work that was accepted for publication in the International Review of Financial Analysis. Changes resulting from the publishing process, such as peer review, editing, corrections, structural formatting, and other quality control mechanisms may not be reflected in this document. Changes may have been made to this work since it was submitted for publication. A definitive version was subsequently published in the International Review of Financial Analysis, 30 (2013) DOI: 10.1016/j.irfa.2013.05.007 


\title{
Idiosyncratic Volatility and the Pricing of Poorly-Diversified Portfolios
}

\author{
Joëlle Miffre*, Chris Brooks** and Xiafei Li***
}

\begin{abstract}
This article examines the role of idiosyncratic volatility in explaining the cross-sectional variation of size- and value-sorted portfolio returns. We show that the premium for bearing idiosyncratic volatility varies inversely with the number of stocks included in the portfolios. This conclusion is robust within various multifactor models based on size, value, past performance, liquidity and total volatility and also holds within an ICAPM specification of the risk-return relationship. Our findings thus indicate that investors demand an additional return for bearing the idiosyncratic volatility of poorly-diversified portfolios.
\end{abstract}

* Joëlle Miffre, EDHEC Business School, 393 Promenade des Anglais, 06202, Nice, France. Tel: +33 (0)4 931832

55, E-mail: Joelle.Miffre@edhec.edu

** Chris Brooks, ICMA Centre, University of Reading, Whiteknights, PO Box 242, Reading, RG6 6BA, UK, Tel:

+44 (0)118 378 8239, Email: c.brooks@ icmacentre.rdg. ac.uk

*** Xiafei Li, Nottingham University Business School, University of Nottingham, Jubilee Campus, Nottingham,

NG8 1BB, UK, Tel: +44 (0) 115 8466436, Email: Xiafei.Li@nottingham. ac.uk

Keywords: idiosyncratic volatility, cross-sectional variation in stock returns, diversification.

JEL classifications: G12, G14

This version: April 2013

Acknowledgement: we would like to thank the editor and two anonymous referees for their comments. Any remaining errors are ours. 


\section{Introduction}

One of the main tenets of modern portfolio theory is that differences in returns are solely driven by differences in systematic risk and thus that idiosyncratic volatility has no role to play in explaining why some stocks or portfolios generate higher returns than others (see for example, the CAPM of Sharpe, 1964 and Lintner, 1965). Yet, other theoretical models such as Merton (1987) and Malkiel and Xu (2002) posit that idiosyncratic volatility commands a positive risk premium and thus that the relationship between idiosyncratic volatility and mean returns, far from being flat, is positive. ${ }^{1}$

The relationship between idiosyncratic volatility and mean returns has been the subject of an intense debate in the empirical asset pricing literature too. A majority of articles conclude that idiosyncratic volatility is not priced (Fama and MacBeth, 1973; Bali et al., 2005; Huang et al., 2010; Han and Lesmond, 2011; Fink et al., 2012; Miffre et al., 2012). Other articles, however, put forward the case that stocks with higher idiosyncratic volatility command higher risk premium (Goyal and Santa-Clara, 2003; Jiang and Lee, 2006; Diavatopoulos et al., 2008; Fu, 2009; Garcia et al., 2010). Finally, and perhaps most puzzlingly, Ang et al. (2006, 2009) and Guo and Savickas (2010) argue that the relationship between idiosyncratic volatility and mean returns is negative: stocks with high (low) idiosyncratic volatility earn lower (higher) mean returns on average. Interestingly Bali and Cakici (2008) are unable to find a reliable and consistent relationship between idiosyncratic volatility and portfolio returns - they find statistically

${ }^{1}$ Because of incomplete information, transaction costs or institutional restrictions such as taxes or liquidity constraints, investors are unable to hold the true market portfolio and thus are forced to care about both systematic and idiosyncratic risks. In equilibrium they should therefore demand a premium that is proportionate to the idiosyncratic risk they take. 
insignificant; positive and significant; and negative and significant results when they examine the data in different ways. While the lack of consensus on the sign of the idiosyncratic volatility premium could be attributed to how the idiosyncratic volatility signal was extracted, ${ }^{2}$ other explanations relating to the weighting scheme used (value versus equal-weighting), the data frequency, dataset or time period in $\mathrm{use}^{3}$ have also been brought forward as possible reasons for the diverging conclusions. Finally, it is interesting to note that the relevance of idiosyncratic risk may not be confined to the US, but is also priced in 23 international markets (Ang et al., 2009), in the UK (Angelidis and Tessaromatis, 2008) and in China (Drew et al., 2004).

Another enduring strand of literature on idiosyncratic volatility focuses on the number of stocks that are needed to ensure good diversification. An earlier study by Evans and Archer (1968) reports that by holding a portfolio with more than eight randomly selected stocks, unsystematic variation can be significantly reduced. Elton and Gruber (1977) demonstrate that a portfolio containing more than 15 stocks provides sufficient diversification at the time of writing. Later, Statman (1987) reveals that a well-diversified portfolio should include a minimum of 3040 stocks. Yet more recently, the study by Campbell et al. (2001) argues that to achieve full diversification, the number of randomly selected stocks should be increased to $50 . \mathrm{Xu}$ and Malkiel (2003) contend further that idiosyncratic volatility has become more important over time

\footnotetext{
${ }^{2}$ While most papers extract the idiosyncratic volatility signal from the market or Fama and French (1993) models, other authors either base their inference on firm's traded options (Diavatopoulos et al., 2008), estimate an EGARCH model (Fu, 2009) or adopt a model-free approach (Garcia et al., 2010). Accounting for short-term negative autocorrelation (Huang et al., 2010) and contango (Miffre et al., 2012) also seems to impact the conclusions on the pricing of idiosyncratic volatility.

${ }^{3}$ Bali et al. (2005) suggest that the findings of Goyal and Santa-Clara (2003) are in fact spuriously caused by small, illiquid NASDAQ stocks, and period specific (disappearing after 2000). The role of seasonality is noted by Huang et al. (2011) in determining the strength of the idiosyncratic volatility-return relationship.
} 
since the 1960's as the proportion of institutional investors, who may unintentionally cluster their purchase and sales activities, grew and as stocks listed on the NASDAQ increased in number and importance. Kearney and Potì (2008) examine the issue of diversification in an European context and find that stocks have become more volatile so that it took 166 stocks in 2003 versus merely 35 in 1974 to diversify idiosyncratic risk away. ${ }^{4}$

Altogether, the lack of agreement in existing research merely serves to illustrate the fragility of extant conclusions on idiosyncratic volatility and its role in explaining the crosssectional variation in returns. In this paper, we reconsider the issue of the number of stocks required to diversify a portfolio, but unlike existing studies, we do this by investigating whether idiosyncratic volatility is priced for size and value-sorted Fama and French (1992) portfolios containing different numbers of stocks. We show that cross-sectional differences in average returns directly and positively relate to differences in the idiosyncratic volatility of the portfolio returns. More specifically, we reveal that, in a fashion unrelated to Fama and French (1993), past performance, market volatility, or liquidity factors, investors demand a positive (albeit mostly insignificant) idiosyncratic volatility premium for holding portfolios that include less than 20 stocks. The premium for bearing idiosyncratic volatility then decreases as the number of assets included in the size and BM-sorted portfolios rises. These results are in line with the notion that agents who fail to fully diversify their portfolios demand higher average returns to compensate them for bearing increased levels of firm-specific risk (Merton, 1987; Malkiel and Xu, 2002).

\footnotetext{
${ }^{4}$ Kearney and Potì (2008) argue that this result is not due to a rise in stock return correlations, but rather to the fact that idiosyncratic risk itself has gone up. A possible explanation that they highlight is a divergence between individuals' and institutional investor sentiment together with a rise in the proportion of institutional investors; alternatively, it may be that idiosyncratic risk has risen due to an increase in the speculative trading volumes of retail investors.
} 
It is evident that optimally spreading risks across assets is not costless and that information is not freely and fully available. This argument discussed in many studies (see, for example, Malkiel and $\mathrm{Xu}, 2002$ ) concerning the frictions to full diversification that may exist in practice are sufficient to justify why an idiosyncratic risk premium may arise. This line of reasoning would lead us to believe that the price of idiosyncratic volatility (i.e. the price per unit of idiosyncratic risk) should be the same for all portfolios whether they are well diversified or not since all portfolios will be held by the same marginal investor. Our finding of different idiosyncratic risk premia for portfolios containing different number of stocks may arise if the portfolios are held by distinct groups of investors with varying risk tolerances - in other words, if capital markets are segmented. ${ }^{5}$ Errunza and Losq (1985) develop a model of partial market segmentation that may arise from restrictions on foreign ownership for some assets but not others. However, segmentation may arise even in the absence of such restrictions where there are systematic and permanent clientele effects in the investment decisions made by different groups of investors. For instance, it may be that large, international companies have both international and domestic investor bases, whereas smaller, less well known companies may have only local investors. Indeed, it has been reported that large capitalization stocks are well integrated into world capital markets but small cap stocks are more segmented (see, for example, Heston et al., 1995). It may also be that institutional investors, who are holding large, well diversified portfolios and therefore do not require compensation for idiosyncratic risk are focused predominantly on large capitalization and growth stocks. On the other hand, individual investors may be holding small, poorly diversified portfolios but are also investing in small cap value

\footnotetext{
${ }^{5} \mathrm{We}$ are grateful to an anonymous referee for suggesting this line of argument.
} 
stocks. To the extent that individual investors do not have sufficient investment capital to form well diversified portfolios through direct equity investment and institutions are precluded from investing in small cap stocks by the price impact that their investments would have on these illiquid and shallow markets, these two groups of investors will hold quite different portfolios even in the long run. ${ }^{6}$ In these circumstances, the usual forces of arbitrage will be insufficient to elicit a change in their holdings.

The rest of the study is organized as follows. Section II presents the methodology employed to study the relationship between time-varying idiosyncratic volatility and portfolio returns. Section III describes the data. Section IV reports the results and finally section V offers some concluding remarks.

\section{Methodology}

We employ the two-step methodology of Fama and MacBeth (1973) to test for the pricing of idiosyncratic volatility within portfolios with increasing numbers of stocks. In the first step, we run regressions of the excess returns of size and B/M-sorted equity portfolios on a set of risk factors:

$$
\mathrm{R}_{\mathrm{P}, \mathrm{t}}=\alpha_{\mathrm{P}}+\beta_{\mathrm{P}} \mathrm{F}_{\mathrm{t}}+\varepsilon_{\mathrm{P}, t}
$$

where $R_{P, t}$ are the time $t$ excess returns of size- and B/M-sorted portfolios of Fama and French (1992), $P \in\{1,2, \ldots 100\}, F_{t}$ is a vector of risk premiums that are known to explain cross-

\footnotetext{
${ }^{6}$ Likewise, Fu and Schutte (2009) suggest intuitively that idiosyncratic volatility will be more highly priced for stocks where there is a higher proportion of retail investors, who tend to be less diversified. For firms where the majority of stocks is held by institutions, they show that there is much less evidence that idiosyncratic volatility is priced.
} 
sectional equity returns or shocks to a set of state variables that serve as hedges against unwelcome shifts in agents' investment opportunity sets according to the Intertemporal CAPM of Merton (1973), $\beta_{P}$ is a vector of sensitivities of portfolio $P$ to these $K$ risk premiums or risk factors, $\alpha_{P}$ is a constant and $\varepsilon_{P t}$ is an error term.

Model (1) is first estimated over the sample January 1968 to December 1972. We then calculate the standard deviation of the residuals from (1) over the window as $\operatorname{IVol}_{P}=\sigma\left(\varepsilon_{P, t}\right)$, and this forms the measure of idiosyncratic volatility that we employ. By constructing it in this way, we ensure that idiosyncratic volatility is orthogonal to the risk factors. Both the measures of risk $\left(\beta_{P}\right)$ and the measure of idiosyncratic volatility are used in a second step to explain cross-sectional mean excess returns in each month $k$ from January 1973 to December 1973. The cross-sectional regression in a given month $t+k$ is:

$$
\mathrm{R}_{\mathrm{P}, \mathrm{t}+\mathrm{k}}=\lambda_{0, t+\mathrm{k}}+\lambda_{t+\mathrm{k}} \beta_{\mathrm{P}}+\lambda_{\mathrm{IVol}, \mathrm{t}+\mathrm{k}} \mathrm{IVol}_{\mathrm{P}}+\vartheta_{\mathrm{P}, \mathrm{t}+\mathrm{k}}
$$

where the subscript $P(\in\{1,2, \ldots 100\})$ denotes size and BM-sorted portfolios of Fama and French (1992), $\lambda$ is a $K$-vector of prices of risk associated with the factor mimicking portfolios or state variables $F_{t}, \lambda_{I V o l}$ is the price of idiosyncratic volatility, $\lambda_{0}$ is an intercept and $\vartheta_{P}$ is an error term. This step produces 12 estimates of the vector $\left\{\lambda_{0}, \lambda, \lambda_{\text {IVol }}\right\}$. Finally, the sample is rolledover by 12 observations at a time, with each repetition of the two steps producing 12 new estimates of each of the factor risk premia. $t$-tests are then performed on the resulting risk premia to determine which factors have explanatory power for the cross-section of realized stock returns.

The purpose of the article is to test whether investors demand a risk premium for holding portfolios that are poorly diversified (i.e. that includes relatively few stocks). If so, $\lambda_{I V o l}$ should be positive and significant. In line with the discussion above concerning market segmentation, we 
also consider whether investors demand higher expected returns for holding poorly diversified portfolios. To test these ideas, we perform the two-step approach for portfolios containing different numbers of stocks. Thus, the first set of regressions include from the 100 portfolios of Fama and French (1992) only those that contain no more than 20 stocks in the first step regression. We then repeat this analysis for only portfolios containing at most 25, 30, 40, 50, 60, $70,80,90,100,120,140,160,180,200$ stocks. $^{7}$ Each time, we test the null hypothesis that $\lambda_{\mathrm{IVol}}=\mathbf{0}$. We also test this hypothesis for all 100 size and BM-sorted portfolios of Fama and French (1992).

When we restrict $N$ (the maximum number of stocks included in a given portfolio) to be as low as 20 , the resulting number of portfolios that meet the criterion of having at most $N$ stocks can be as small as 17 . The small sample size may then lead to the statistical tests lacking power, especially in the presence of non-normally distributed errors. To obtain robust inferences on the pricing of idiosyncratic volatility, we run the following bootstrap procedure:

i) The Fama and French (1992) portfolio returns $\mathrm{R}_{\mathrm{P}, \mathrm{t}}$ and the set of risk premia or risk factors $F_{t}$ are re-sampled with replacement simultaneously and the bootstrapped series are used to estimate $\beta_{P}$ and $\mathrm{IVol}_{P}$ in equation (1);

ii) Step $i$ ) is repeated 100 times; this generates 100 vectors of $\beta_{P}$ and 100 estimates of IVol $_{P}$ per portfolio that meets the requirement of containing at most $N$ stocks;

${ }^{7}$ Again the maximum number of stocks is calculated over the period corresponding to the first-step regression. 
iii) The bootstrapped estimates of $\beta_{P}$ and $\mathrm{IVol}_{P}$ are then used in the second step crosssectional regressions of Fama and MacBeth (1973) to explain actual portfolio returns in months $t+k, k=1,2, \ldots, 12 .^{8}$

We test the robustness of our conclusions on the pricing of idiosyncratic volatility by using different factor models in equation (1). For example, we employ the standard three-factor Fama and French (1993) model and four-factor Carhart (1997) model. Pastor and Stambaugh (2003) show that stock returns are significantly and positively related to a market-wide liquidity risk factor, and Han and Lesmond (2011) further argue that the usefulness of idiosyncratic volatility as an asset pricing factor is crucially affected by liquidity. Therefore, two additional specifications of the pricing regression (1) augment the Carhart (1997) model with the liquidity risk premium of Pastor and Stambaugh (2003) and with the liquidity risk premium and two portfolios based on short-term and long-term reversals (see, for example, Conrad and Kaul, 1989; De Bondt and Thaler, 1985, 1987). ${ }^{9}$ We also test the robustness of our conclusions regarding the pricing of idiosyncratic volatility to the inclusion of a risk factor that proxies for total risk measured via the VIX volatility index (see, for example, Pan, 2002) and finally we estimate an Intertemporal CAPM similar to that of Petkova (2006).

${ }^{8}$ Ideally, we would use considerably more than 100 bootstrapped samples; however, given that we are resampling as part of a two-stage process, the procedure is highly computer intensive and therefore employing a non-trivially larger number of replications is infeasible.

${ }^{9}$ Huang et al. (2010) explain the negative relationship between idiosyncratic volatility and mean returns observed in Ang et al. $(2006,2009)$ via return reversals; thus allowing for short-term reversals in our specification of the risk-return relationship seems important. 


\section{Data}

Our dataset comprises the monthly returns on the 100 size- and B/M-sorted portfolios of Fama and French (1992) as provided on the website of Kenneth French. It also includes the equity risk premium, the size premium (SMB), the value premium (HML), the portfolios formed on short and long-term reversals as provided by Kenneth French and the liquidity risk premium as provided by Robert Stambaugh. The start date for the sample is dictated by data availability for the liquidity risk premium. The sample spans the period January 1968 to December 2011. The value-weighted return on all NYSE, AMEX, and NASDAQ stocks in excess of the one-month Treasury bill rate is used as a proxy for the market risk premium. We also download from Kenneth French's website the number of stocks included in the 100 size and B/M-sorted portfolios as this information is crucial to our testing of whether there is an inverse relationship between the number of stocks included in a portfolio and the pricing of its idiosyncratic volatility.

Following Petkova (2006), our intertemporal CAPM uses as proxies for the state variables deemed to hedge unwelcome changes in investment opportunities: $i$ ) the dividend yield on the S\&P500 composite index (DY, obtained from Datastream), ii) default spread (DS, measured as the difference in yields between BAA- and AAA-rated bonds and obtained from the St. Louis FED), iii) the slope of the term structure of interest rates (TS, measured as the difference in yields between 10-year government bonds and 3-month Treasury-bills and obtained from Datastream) and $i v$ ) the 3-month Treasury-bill rate (TB, obtained from Datastream). Shocks to the state variables $\left(\mathrm{u}_{\mathrm{t}}^{\mathrm{DY}}, \mathrm{u}_{\mathrm{t}}^{\mathrm{DS}}, \mathrm{u}_{\mathrm{t}}^{\mathrm{TS}}\right.$ and $\mathrm{u}_{\mathrm{t}}^{\mathrm{TB}}$ ) are modeled using the following VAR(1) specification: 


$$
\left(\begin{array}{c}
\mathrm{R}_{\mathrm{M}, \mathrm{t}} \\
\mathrm{DY}_{\mathrm{t}} \\
\mathrm{DS}_{\mathrm{t}} \\
\mathrm{TS}_{\mathrm{t}} \\
\mathrm{TB}_{\mathrm{t}}
\end{array}\right)=A\left(\begin{array}{c}
\mathrm{R}_{\mathrm{M}, \mathrm{t}-1} \\
\mathrm{DY}_{\mathrm{t}-1} \\
\mathrm{DS}_{\mathrm{t}-1} \\
\mathrm{TS}_{\mathrm{t}-1} \\
\mathrm{~TB}_{\mathrm{t}-1}
\end{array}\right)+\left(\begin{array}{c}
\mathrm{u}_{\mathrm{t}}^{\mathrm{M}} \\
\mathrm{u}_{\mathrm{t}}^{\mathrm{DY}} \\
\mathrm{u}_{\mathrm{t}}^{\mathrm{DS}} \\
\mathrm{u}_{\mathrm{t}}^{\mathrm{TS}} \\
\mathrm{u}_{\mathrm{t}}^{\mathrm{TB}}
\end{array}\right)
$$

where $R_{M, t}$ stands for the excess returns on the market. Following Petkova (2006), all the

variables are first demeaned; the residuals $\mathrm{u}_{\mathrm{t}}^{\mathrm{DY}}, \mathrm{u}_{\mathrm{t}}^{\mathrm{DS}}, \mathrm{u}_{\mathrm{t}}^{\mathrm{TS}}$ and $\mathrm{u}_{\mathrm{t}}^{\mathrm{TB}}$ are orthogonalized with respect to the market excess returns and then standardized so that they have zero-mean and a standard deviation equal to that of $\mathrm{u}_{\mathrm{t}}^{\mathrm{M}}$. The resulting four series can be considered as shocks to the state variables that proxy for changes in the investment opportunity set of agents over time. As such, they can enter the intertemporal CAPM pricing equation (1) alongside the market excess returns. The VIX series is obtained from the CBOE.

\section{Empirical Results}

Table 1 presents the average prices of risk associated with the three factors of Fama and French (1993) and of idiosyncratic volatility together with their associated $t$-ratios. The market risk premium, $\lambda_{M}$, declines almost monotonically as the maximal number of stocks in the portfolio increases; it is never statistically significant and is negative when the portfolios contain at least 70 stocks or more. On the other hand, the size and value factors are always positive, and are significant in some cases (all portfolios with at least 25 stocks in the case of HML); interestingly, the size premium declines monotonically as the number of stocks increases, while the value premium generally increases. The idiosyncratic volatility premium, $\lambda_{\text {IVol }}$, declines almost continually as the maximum number of stocks in the portfolios increases. Although it is never significant, the idiosyncratic volatility premium has a financially meaningful magnitude. For 
example, $\lambda_{I V o l}$ is equal to 0.0654 for portfolios that include up to 20 stocks, indicating that investors who are not well diversified require a $0.0654 \%$ increase in monthly mean returns per $1 \%$ increase in the idiosyncratic volatility of their portfolios. On the other hand, the idiosyncratic volatility premia are mostly negative but much smaller in magnitude when the portfolios comprising more stocks are also included in the cross-sectional regressions.

The final row of Table 1 (Panel B) presents the differences between the idiosyncratic volatility premia for portfolios with up to 20 stocks compared with those including portfolios with higher numbers of stocks, and in parentheses we display the $t$-statistics for the null hypothesis that there is no difference between these idiosyncratic volatility premia. It is clear that all of these differences are positive (that is, the idiosyncratic volatility premium is higher when the large stock portfolios are omitted from the cross-sectional regressions), and in most cases significantly so. For instance, this premium is 0.0628 ( $0.0628 \%$ per month per unit of risk) higher for the maximum 20-stock portfolio than for the maximum 30-stock portfolio, with t-ratio 2.69, significant at the 5\% level. Another interpretation of these results is that portfolios with 30 stocks or more can be considered well diversified, while those with 25 or fewer cannot. ${ }^{10}$

Table 2 presents the findings from applying a similar methodology, but now additionally including a fourth factor for momentum in the model, following Carhart (1997). As the results show, the momentum risk premium is not statistically significant in any of the entries in Table 2, and thus we can conclude that "momentum risk" is not priced in the 100-portfolio cross-section

\footnotetext{
${ }^{10}$ In unreported results, we calculate the correlations between the prices of idiosyncratic volatility and the number of stocks included in the portfolio; we also calculate the correlations between the $t$-ratios of the prices of idiosyncratic volatility and the number of stocks included in the portfolio for all sets of models that we estimate. We find that irrespective of the model, all correlations are large and negative: of the order -0.8 , indicating very strongly that the relationship between the number of stocks in the portfolio and the idiosyncratic volatility premium is negative.
} 
sorted on size and book-to-market. The other results, including those for idiosyncratic volatility, are virtually unchanged compared with those in Table 1.

Tables 3 and 4 again employ the same approach as above, but further add variables to capture the liquidity risk premium (Table 3 ) and the liquidity risk premium plus factors to capture short- and long-term return reversals (Table 4). Considering first the liquidity risk premium in Table 3, it can be seen that it is highly significant for all portfolios containing 40 stocks or more, and increases substantially in size from 0.0005 for the maximum 20 -stock portfolio to reach 0.028 for the maximum 50-stock portfolio. It then remains at approximately this level as the maximum number of stocks increases (i.e., moving from left to right across the table). It is evident, however, that the findings from the previous tables on idiosyncratic volatility remain largely unaltered, both in terms of the sizes of the coefficients, and the differences between the maximum 20-stock portfolio and the others in the last rows of Tables 3 and 4 . We can thus conclude that, in contrast to the suggestion of Han and Lesmond (2011), we cannot attribute the idiosyncratic volatility premium that we observe to illiquidity; the two are statistically distinct phenomena. Finally, there is a significant risk premium for long- but not short-term reversals: the prices of risk associated with the former are statistically significant and positive for almost all the columns in Table 4 except for those including only very small numbers of stocks (20 or fewer), whereas the prices of risk associated with short-term reversals are positive but rarely significant. The magnitudes of both the idiosyncratic volatility premia and their differences compared with the premia modeled from the 20 -stock portfolio (as reported in the last two rows of Table 4) are reduced compared to their corresponding values in the previous tables and become negative for portfolios containing at least 30 stocks. Yet, as we increase the number of securities in the portfolios, the key features of decreasing idiosyncratic volatility premia and increasing spreads 
relative to the 20 -stock portfolio still hold within the augmented factor model of Table 4 . This suggests that, in contrast to the conclusions of Huang et al. (2010), the pattern observed in the previous tables remains present when we allow for short-term reversals.

Table 5 repeats the analysis of Table 4, but this time including the measure of market volatility represented by the VIX volatility index. Note that the VIX data are only available from 1986; thus the results presented in Table 5 are based on a shorter sample period than those in all other tables and hence are not strictly comparable. It is clear that the risk premia for market-wide risk as captured by the VIX are all negative and statistically insignificant, although they become almost monotonically larger (i.e., less negative) as we more from left to right across the table. The sizes of the idiosyncratic volatility premia are somewhat altered from their values in the previous tables, although not in a consistent way, but the significances of the differences in these premia between the 20 -stock portfolio and the better diversified ones are diminished, probably as a result of the reduced sample period.

Finally, the results from the intertemporal CAPM approach augmented with idiosyncratic volatility are given in Table 6. It is worth noting that none of the parameters on the macroeconomic variables are significant (with the exception of unexpected changes in the term structure of interest rates, which is positive and significant for the least well diversified portfolios and positive and almost significant for several others; see also Petkova, 2006). We find that the magnitudes of the idiosyncratic risk premia are similar to those in the previous tables, and that the differences between these premia across well diversified versus poorly diversified portfolios (Panel B) are considerably reduced in significance although the parameter values themselves are only slightly smaller. 


\section{Conclusions}

This paper examines whether idiosyncratic volatility explains some of the cross-sectional variations in returns between a set of 100 size- and value-sorted portfolios. In other words, it considers: first, whether idiosyncratic risk is priced; and second, whether the most poorly diversified from amongst these portfolios require greater compensation for the idiosyncratic volatility that they entail than those that are better diversified, against the basic prediction of the CAPM.

Supporting evidence for this hypothesis is provided in Campbell et al. (2001) and by Kearney and Potì (2008), who argue that 50 and over 100 randomly selected stocks respectively are now needed to achieve full diversification as the prices of individual stocks have in general become more interlinked over time. It is also likely that some of the portfolios with smaller numbers of stocks are not sectorally well stratified. For example, it is well known that value portfolios tend to comprise disproportionate numbers of utility, mining and basic manufacturing companies while growth portfolios include more technology, software, advertising firms and pharmaceuticals, leading to persistent, non-trivial levels of industry-specific unsystematic risk in the portfolios.

We show that idiosyncratic volatility commands a premium that is unrelated to the CAPM beta, size, book-to-market ratio, liquidity risk and past performance. More specifically our results suggest that within the Fama and French (1993) model, at least 30 stocks are needed for the premium for bearing idiosyncratic volatility to become insignificant at the $5 \%$ level. To put this differently, investors who hold portfolios with fewer than 30 stocks on average demand a positive (albeit insignificant) idiosyncratic volatility premium. Our paper therefore contributes to the debate on the possible role of unsystematic risk in explaining stock returns. The results are also 
consistent with those reported in Goyal and Santa-Clara (2003), Diavatopoulos et al. (2008), Fu (2009), Garcia et al. (2010) who also found a positive relationship between idiosyncratic volatility and stock market returns.

In practice, it is often the case that institutional investors such as pension and mutual fund managers may end up holding similar stocks that have common characteristics, such as small capitalization, value or growth, past losers or winners (see for example Barberis and Shleifer, 2003; Chan et al., 2002) either by choice or because their mandate is narrow. This investment strategy enables them to simplify their portfolio allocation decisions and to pursue superior performance in a narrowly defined fashion. Since the returns of stocks sharing common characteristics may be highly positively correlated, it might not be possible to achieve adequate diversification even with fairly large numbers of stocks. It may also be the case that there are clientele effects in investment decisions so that certain groups of investors hold well diversified portfolios while others hold smaller numbers of a different style of stocks in their portfolios. It could well be that investors in this latter group require compensation for idiosyncratic risk while those in the former do not.

Therefore, it would be interesting for future research to determine the extent to which the portfolios of actual fund managers and of retail investors are subject to idiosyncratic volatility and the relationship between this and their relative performances. It would also be of relevance to test whether the Fama and French (1993) portfolios with small numbers of stocks are poorly diversified across industries as well as being specialized in terms of their styles, and thus whether sectoral concentration can explain some of the idiosyncratic volatility premium that we observe in this study. 


\section{References}

Angelidis, T. and N. Tessaromatis "Idiosyncratic volatility and equity returns: UK evidence." International Review of Financial Analysis, 17 (2008), 539-556.

Ang, A.; R. J. Hodrick; Y. Xing; and X. Zhang. "The Cross-Section of Volatility and Expected Returns." Journal of Finance, 61 (2006), 259-299.

Ang, A.; R. J. Hodrick; Y. Xing; and X. Zhang. "High Idiosyncratic Volatility and Low Returns: International and Further U.S. Evidence." Journal of Financial Economics, 91 (2009), 1-23.

Bali, T. G., and N. Cakici. "Idiosyncratic Volatility and the Cross-Section of Expected Returns." Journal of Financial and Quantitative Analysis 43 (2008), 29-58.

Bali, T. G.. ; N. Cakici ; X. Yan ; and Z. Zhang. "Does Idiosyncratic Risk Really Matter?" Journal of Finance, 60 (2005), 905-929.

Barberis, N., and A. Shleifer. "Style Investing." Journal of Financial Economics 68 (2003), 161199.

Campbell, J. Y.; M., Lettau; B. G., Malkiel; and Y. Xu. "Have Individual Stocks Become More Volatile? An Empirical Exploration of Idiosyncratic Risk." Journal of Finance, 56 (2001), $1-43$.

Carhart, M. "On persistence of mutual fund performance. " Journal of Finance, 52 (1997) 57-82.

Chan, L. K. C.; H.-L. Chen; and J. Lakonishok. "On Mutual Fund Investment Style." Review of Financial Studies 15 (2002), 1407-1437.

Conrad, J.; and G., Kaul, Mean reversion in short-horizon expected returns, Review of Financial Studies (1989) 2, 225-240

De Bondt, W.; and Thaler, R. "Does Stock Market Overreact?." Journal of Finance, 40 (1985), 793-807.

De Bondt, W.; and Thaler, R. "Further Evidence on Investor Overreaction and Stock Market Seasonality." Journal of Finance 42 (1987), 557-581.

Diavatopoulos, D.; J. S. Doran; and D. R. Peterson. "The Information Content in Implied Idiosyncratic Volatility and the Cross-Section of Stock Returns: Evidence from the Option Markets." Journal of Futures Markets, 28 (2008), 1013-1039.

Drew, M.E., T. Naughton, and M. Veeraraghavan. "Is idiosyncratic volatility priced? Evidence from the Shanghai Stock Exchange." International Review of Financial Analysis, 13 (2004), 349-366. 
Elton, E. J., and M. J. Gruber. "Risk Reduction and Portfolio Size: An analytical Solution." Journal of Business, 50 (1977), 415-437.

Errunza, V. and E. Losq. "Internal Asset Pricing under Mild Segmentation: Theory and Tests." Journal of Finance 40 (1985), 105-124.

Evans, J. L. and S. H. Archer. "Diversification and the Reduction of Dispersion: An Empirical Analysis." Journal of Finance, 23 (1968), 761-767.

Fama, E. F., and K. R. French. "The Cross-Section of Expected Stock Returns." Journal of Finance, 47 (1992), 427-465.

Fama, E. F., and K. R. French. "Common Risk Factors in the Returns on Stocks and Bonds." Journal of Financial Economics, 3 (1993), 3-56.

Fama, E. F., and J. D., MacBeth. "Risk, Returns, and Equilibrium: Empirical Tests." Journal of Political Economy, 81 (1973), 607-636.

Fink, J.; K., Fink; and H., He. "Expected Idiosyncratic Volatility Measures and Expected Return", Financial Management, 41 (2012), 719-767

$\mathrm{Fu}$, F. "Idiosyncratic Risk and the Cross-section of Expected Stock Returns." Journal of Financial Economics, 91 (2009), 24-37.

$\mathrm{Fu}, \mathrm{F}$., and M. Schutte. "Investor Diversification and the Pricing of Idiosyncratic Risk." Working Paper, Singapore Management University (2009).

Garcia, R.; Mantilla-Garcia, D.; and L., Martellini. "A Model-Free Measure of Aggregate Idiosyncratic Volatility and the Prediction of Market Returns." (2010) Journal of Financial and Quantitative Analysis, forthcoming.

Goyal, A., and P. Santa-Clara. "Idiosyncratic Risk Matters!" Journal of Finance, 58 (2003), 9751007.

Guo, H.; and R., Savickas. "Relation between Time-Series and Cross-Sectional Effects of Idiosyncratic Variance on Stock Returns." Journal of Banking and Finance, 34, 7 (2010), 1637-1649.

Han, Y.; and D. Lesmond. "Liquidity Biases and the Pricing of Cross-Sectional Idiosyncratic Volatility." Review of Financial Studies 24 (2011), 1590-1629.

Huang, W.; Q. Liu; S. G. Rhee; and L. Zhang. "Return reversals, idiosyncratic risk and expected returns." Review of Financial Studies, 23 (2010), 147-168.

Huang, W.; Q. Liu; S. G. Rhee; and L. Zhang. "Another Look at Idiosyncratic Volatility and Expected Returns." Journal of Investment Management, 9 (2011), 1-26. 
Heston, S.L., K.G. Rouwenhorst; and R.E. Wessels. "The Structure of International Stock Returns and Integration of Capital Markets." Journal of Empirical Finance 2 (1995), 173197.

Jiang, X., and B-S. Lee. "The Dynamic Relation between Returns and Idiosyncratic Volatility." Financial Management, 35 (2006), 43-65.

Kearney, C. and V. Potì. (2008) "Have European Stocks become More Volatile? An Empirical Investigation of Idiosyncratic and Market Risk in the Euro Area." European Financial Management 14 (2008), 419-444.

Lintner, J. "The Valuation of Risky Assets and the Selection of Risky Investments in Stock Portfolios and Capital Budgets." Review of Economics and Statistics, 47 (1965), 13-37.

Malkiel, B., and Y. Xu. "Idiosyncratic Risk and Security Returns." Working Paper, University of Texas at Dallas (2002).

Merton, R.C. "An Intertemporal Capital Asset Pricing Model." Econometrica, 41, 5 (1973), 867887.

Merton, R.C. "A Simple Model of Capital Market Equilibrium with Incomplete Information." Journal of Finance, 42 (1987), 483-510.

Miffre, J.; A.M., Fuertes; and A. Fernandez-Perez. "Idiosyncratic Volatility and Commodity Futures Returns." EDHEC Business School, Working paper (2012).

Pan, J. (2002) "The Jump-risk Premia Implicit in Options: Evidence from an Integrated TimeSeries Study." Journal of Financial Economics 63 (2002) 3-50.

Pastor, L. and R. F. Stambaugh "Liquidity Risk and Expected Stock Returns" Journal of Political Economy 111 (2003), 642-685.

Petkova, R. "Do the Fama-French Factors Proxy for Innovations in Predictive Variables?" Journal of Finance, 61 (2006) 581-612.

Sharpe, W. F. "Capital asset prices: A Theory of Market Equilibrium under Conditions of Risk." Journal of Finance, 19 (1964), 425-442.

Statman, M. "How Many Stocks Make a Diversified Portfolio?" Journal of Financial and Quantitative Analysis, 22 (1987), 353-363.

Xu, Y., and B. G. Malkiel. "Investigating the Behavior of Idiosyncratic Volatility." Journal of Business, 76 (2003), 613-644. 


\section{Table 1: Pricing of idiosyncratic volatility within the Fama and French (1993) model}

The table presents averages for the prices of risk associated with the three factors of Fama and French (1993) and the price of idiosyncratic volatility. The prices of risk are estimated from the second-step of Fama and MacBeth (1973) regressions over the period January 1973 December 2011. $N$ is the maximum number of stocks included in the portfolios, ALL means that the 100 Fama and French (1992) portfolios were considered in the cross-sectional regressions. $\lambda_{\mathrm{IVol}}(20)-\lambda_{\mathrm{IVol}}(N)$ measures the difference in the prices of idiosyncratic volatility for the portfolio with 20 stocks and the portfolio with $N$ stocks. $t$-statistics are in parentheses.

\begin{tabular}{|c|c|c|c|c|c|c|c|c|c|c|c|c|c|c|c|c|}
\hline$N<=$ & 20 & 25 & 30 & 40 & 50 & 60 & 70 & 80 & 90 & 100 & 120 & 140 & 160 & 180 & 200 & ALL \\
\hline \multicolumn{17}{|c|}{ Panel A: Estimated prices of risk } \\
\hline$\lambda_{0}$ & $\begin{array}{r}0.0024 \\
(0.96)\end{array}$ & $\begin{array}{r}0.0032 \\
(1.38)\end{array}$ & $\begin{array}{r}0.0043 \\
(1.93)\end{array}$ & $\begin{array}{r}0.0047 \\
(2.25)\end{array}$ & $\begin{array}{r}0.0047 \\
(2.32)\end{array}$ & $\begin{array}{r}0.0051 \\
(2.62)\end{array}$ & $\begin{array}{r}0.0054 \\
(2.75)\end{array}$ & $\begin{array}{r}0.0056 \\
(2.93)\end{array}$ & $\begin{array}{r}0.0060 \\
(3.15)\end{array}$ & $\begin{array}{r}0.0062 \\
(3.26)\end{array}$ & $\begin{array}{r}0.0066 \\
(3.46)\end{array}$ & $\begin{array}{r}0.0068 \\
(3.60)\end{array}$ & $\begin{array}{r}0.0069 \\
(3.68)\end{array}$ & $\begin{array}{r}0.0070 \\
(3.72)\end{array}$ & $\begin{array}{r}0.0068 \\
(3.66)\end{array}$ & $\begin{array}{r}0.0082 \\
(4.51)\end{array}$ \\
\hline$\lambda_{\mathrm{M}}$ & $\begin{array}{r}0.0013 \\
(0.70)\end{array}$ & $\begin{array}{r}0.0010 \\
(0.65)\end{array}$ & $\begin{array}{r}0.0008 \\
(0.59)\end{array}$ & $\begin{array}{r}0.0004 \\
(0.28)\end{array}$ & $\begin{array}{r}0.0005 \\
(0.41)\end{array}$ & $\begin{array}{r}0.0001 \\
(0.10)\end{array}$ & $\begin{array}{r}-0.0001 \\
(-0.11)\end{array}$ & $\begin{array}{r}-0.0004 \\
(-0.35)\end{array}$ & $\begin{array}{r}-0.0007 \\
(-0.59)\end{array}$ & $\begin{array}{r}-0.0009 \\
(-0.72)\end{array}$ & $\begin{array}{r}-0.0011 \\
(-0.92)\end{array}$ & $\begin{array}{r}-0.0014 \\
(-1.15)\end{array}$ & $\begin{array}{r}-0.0015 \\
(-1.20)\end{array}$ & $\begin{array}{r}-0.0015 \\
(-1.18)\end{array}$ & $\begin{array}{r}-0.0014 \\
(-1.11)\end{array}$ & $\begin{array}{r}-0.0021 \\
(-1.59)\end{array}$ \\
\hline$\lambda_{\mathrm{SMB}}$ & $\begin{array}{r}0.0036 \\
(2.61)\end{array}$ & $\begin{array}{r}0.0031 \\
(2.27)\end{array}$ & $\begin{array}{r}0.0024 \\
(1.92)\end{array}$ & $\begin{array}{r}0.0021 \\
(1.78)\end{array}$ & $\begin{array}{r}0.0021 \\
(1.67)\end{array}$ & $\begin{array}{r}0.0020 \\
(1.58)\end{array}$ & $\begin{array}{r}0.0017 \\
(1.41)\end{array}$ & $\begin{array}{r}0.0017 \\
(1.37)\end{array}$ & $\begin{array}{r}0.0017 \\
(1.40)\end{array}$ & $\begin{array}{r}0.0017 \\
(1.39)\end{array}$ & $\begin{array}{r}0.0016 \\
(1.31)\end{array}$ & $\begin{array}{r}0.0016 \\
(1.26)\end{array}$ & $\begin{array}{r}0.0015 \\
(1.18)\end{array}$ & $\begin{array}{r}0.0015 \\
(1.16)\end{array}$ & $\begin{array}{r}0.0014 \\
(1.12)\end{array}$ & $\begin{array}{r}0.0012 \\
(0.92)\end{array}$ \\
\hline$\lambda_{\mathrm{HML}}$ & $\begin{array}{r}0.0020 \\
(1.51)\end{array}$ & $\begin{array}{r}0.0024 \\
(2.08)\end{array}$ & $\begin{array}{r}0.0026 \\
(2.31)\end{array}$ & $\begin{array}{r}0.0024 \\
(2.11)\end{array}$ & $\begin{array}{r}0.0025 \\
(2.08)\end{array}$ & $\begin{array}{r}0.0026 \\
(2.11)\end{array}$ & $\begin{array}{r}0.0030 \\
(2.42)\end{array}$ & $\begin{array}{r}0.0032 \\
(2.54)\end{array}$ & $\begin{array}{r}0.0032 \\
(2.57)\end{array}$ & $\begin{array}{r}0.0033 \\
(2.64)\end{array}$ & $\begin{array}{r}0.0035 \\
(2.80)\end{array}$ & $\begin{array}{r}0.0036 \\
(2.81)\end{array}$ & $\begin{array}{r}0.0037 \\
(2.89)\end{array}$ & $\begin{array}{r}0.0037 \\
(2.89)\end{array}$ & $\begin{array}{r}0.0037 \\
(2.90)\end{array}$ & $\begin{array}{r}0.0040 \\
(3.12)\end{array}$ \\
\hline$\lambda_{\mathrm{IVol}}$ & $\begin{array}{r}0.0654 \\
(1.31)\end{array}$ & $\begin{array}{r}0.0390 \\
(0.89)\end{array}$ & $\begin{array}{r}0.0023 \\
(0.06)\end{array}$ & $\begin{array}{r}0.0117 \\
(0.32)\end{array}$ & $\begin{array}{r}0.0046 \\
(0.13)\end{array}$ & $\begin{array}{r}0.0032 \\
(0.09)\end{array}$ & $\begin{array}{r}-0.0021 \\
(-0.06)\end{array}$ & $\begin{array}{r}-0.0041 \\
(-0.12)\end{array}$ & $\begin{array}{r}-0.0068 \\
(-0.19)\end{array}$ & $\begin{array}{r}-0.0097 \\
(-0.28)\end{array}$ & $\begin{array}{r}-0.0179 \\
(-0.51)\end{array}$ & $\begin{array}{r}-0.0147 \\
(-0.43)\end{array}$ & $\begin{array}{r}-0.0164 \\
(-0.47)\end{array}$ & $\begin{array}{r}-0.0181 \\
(-0.52)\end{array}$ & $\begin{array}{r}-0.0141 \\
(-0.41)\end{array}$ & $\begin{array}{r}-0.0420 \\
(-1.24)\end{array}$ \\
\hline \multicolumn{2}{|c|}{ Panel B: $\lambda_{\mathrm{IVol}}(20)-\lambda_{\mathrm{IVol}}(N)$} & $\begin{array}{r}0.0261 \\
(1.40)\end{array}$ & $\begin{array}{r}0.0628 \\
(2.69)\end{array}$ & $\begin{array}{r}0.0535 \\
(1.84)\end{array}$ & $\begin{array}{r}0.0606 \\
(1.92)\end{array}$ & $\begin{array}{r}0.0619 \\
(1.87)\end{array}$ & $\begin{array}{r}0.0672 \\
(2.00)\end{array}$ & $\begin{array}{r}0.0693 \\
(2.03)\end{array}$ & $\begin{array}{r}0.0720 \\
(2.08)\end{array}$ & $\begin{array}{r}0.0748 \\
(2.15)\end{array}$ & $\begin{array}{r}0.0830 \\
(2.33)\end{array}$ & $\begin{array}{r}0.0799 \\
(2.24)\end{array}$ & $\begin{array}{r}0.0815 \\
(2.30)\end{array}$ & $\begin{array}{r}0.0832 \\
(2.32)\end{array}$ & $\begin{array}{r}0.0793 \\
(2.20)\end{array}$ & $\begin{array}{r}0.1071 \\
(2.93)\end{array}$ \\
\hline
\end{tabular}




\section{Table 2: Pricing of idiosyncratic volatility within the Carhart model}

The table presents averages for the prices of risk associated with the four factors of Carhart (1997) and the price of idiosyncratic volatility. The prices of risk are estimated from the second-step of Fama and MacBeth (1973) regressions over the period January 1973 - December $2011 . N$ is the maximum number of stocks included in the portfolios, ALL means that the 100 Fama and French (1992) portfolios were considered in the cross-sectional regressions. $\lambda_{\mathrm{IVol}}(20)-\lambda_{\mathrm{IVol}}(N)$ measures the difference in the prices of idiosyncratic volatility for the portfolio with 20 stocks and the portfolio with $N$ stocks. $t$-statistics are in parentheses.

\begin{tabular}{|c|c|c|c|c|c|c|c|c|c|c|c|c|c|c|c|c|}
\hline$N<=$ & 20 & 25 & 30 & 40 & 50 & 60 & 70 & 80 & 90 & 100 & 120 & 140 & 160 & 180 & 200 & ALL \\
\hline \multicolumn{17}{|c|}{ Panel A: Estimated prices of risk } \\
\hline$\lambda_{0}$ & $\begin{array}{r}0.0026 \\
(1.02)\end{array}$ & $\begin{array}{r}0.0029 \\
(1.26)\end{array}$ & $\begin{array}{r}0.0043 \\
(1.90)\end{array}$ & $\begin{array}{r}0.0044 \\
(2.10)\end{array}$ & $\begin{array}{r}0.0047 \\
(2.31)\end{array}$ & $\begin{array}{r}0.0049 \\
(2.50)\end{array}$ & $\begin{array}{r}0.0051 \\
(2.59)\end{array}$ & $\begin{array}{r}0.0055 \\
(2.80)\end{array}$ & $\begin{array}{r}0.0058 \\
(2.98)\end{array}$ & $\begin{array}{r}0.0061 \\
(3.15)\end{array}$ & $\begin{array}{r}0.0064 \\
(3.30)\end{array}$ & $\begin{array}{r}0.0064 \\
(3.36)\end{array}$ & $\begin{array}{r}0.0068 \\
(3.55)\end{array}$ & $\begin{array}{r}0.0067 \\
(3.50)\end{array}$ & $\begin{array}{r}0.0066 \\
(3.54)\end{array}$ & $\begin{array}{r}0.0079 \\
(4.32)\end{array}$ \\
\hline$\lambda_{\mathrm{M}}$ & $\begin{array}{r}0.0012 \\
(0.66)\end{array}$ & $\begin{array}{r}0.0012 \\
(0.78)\end{array}$ & $\begin{array}{r}0.0008 \\
(0.53)\end{array}$ & $\begin{array}{r}0.0007 \\
(0.51)\end{array}$ & $\begin{array}{r}0.0006 \\
(0.49)\end{array}$ & $\begin{array}{r}0.0004 \\
(0.31)\end{array}$ & $\begin{array}{r}0.0002 \\
(0.13)\end{array}$ & $\begin{array}{r}-0.0001 \\
(-0.10)\end{array}$ & $\begin{array}{r}-0.0004 \\
(-0.31)\end{array}$ & $\begin{array}{r}-0.0006 \\
(-0.49)\end{array}$ & $\begin{array}{r}-0.0009 \\
(-0.70)\end{array}$ & $\begin{array}{r}-0.0009 \\
(-0.72)\end{array}$ & $\begin{array}{r}-0.0012 \\
(-0.95)\end{array}$ & $\begin{array}{r}-0.0011 \\
(-0.85)\end{array}$ & $\begin{array}{r}-0.0011 \\
(-0.88)\end{array}$ & $\begin{array}{r}-0.0019 \\
(-1.42)\end{array}$ \\
\hline$\lambda_{\mathrm{SMB}}$ & $\begin{array}{r}0.0037 \\
(2.68)\end{array}$ & $\begin{array}{r}0.0030 \\
(2.25)\end{array}$ & $\begin{array}{r}0.0024 \\
(1.93)\end{array}$ & $\begin{array}{r}0.0021 \\
(1.75)\end{array}$ & $\begin{array}{r}0.0020 \\
(1.65)\end{array}$ & $\begin{array}{r}0.0020 \\
(1.58)\end{array}$ & $\begin{array}{r}0.0017 \\
(1.38)\end{array}$ & $\begin{array}{r}0.0017 \\
(1.37)\end{array}$ & $\begin{array}{r}0.0017 \\
(1.39)\end{array}$ & $\begin{array}{r}0.0017 \\
(1.39)\end{array}$ & $\begin{array}{r}0.0017 \\
(1.32)\end{array}$ & $\begin{array}{r}0.0016 \\
(1.26)\end{array}$ & $\begin{array}{r}0.0015 \\
(1.20)\end{array}$ & $\begin{array}{r}0.0015 \\
(1.17)\end{array}$ & $\begin{array}{r}0.0014 \\
(1.13)\end{array}$ & $\begin{array}{r}0.0013 \\
(0.98)\end{array}$ \\
\hline$\lambda_{\mathrm{HML}}$ & $\begin{array}{r}0.0019 \\
(1.48)\end{array}$ & $\begin{array}{r}0.0024 \\
(2.12)\end{array}$ & $\begin{array}{r}0.0027 \\
(2.36)\end{array}$ & $\begin{array}{r}0.0024 \\
(2.14)\end{array}$ & $\begin{array}{r}0.0026 \\
(2.15)\end{array}$ & $\begin{array}{r}0.0026 \\
(2.16)\end{array}$ & $\begin{array}{r}0.0031 \\
(2.44)\end{array}$ & $\begin{array}{r}0.0032 \\
(2.57)\end{array}$ & $\begin{array}{r}0.0032 \\
(2.59)\end{array}$ & $\begin{array}{r}0.0033 \\
(2.67)\end{array}$ & $\begin{array}{r}0.0035 \\
(2.82)\end{array}$ & $\begin{array}{r}0.0036 \\
(2.82)\end{array}$ & $\begin{array}{r}0.0037 \\
(2.90)\end{array}$ & $\begin{array}{r}0.0037 \\
(2.94)\end{array}$ & $\begin{array}{r}0.0037 \\
(2.92)\end{array}$ & $\begin{array}{r}0.0040 \\
(3.10)\end{array}$ \\
\hline$\lambda_{\text {Mom }}$ & $\begin{array}{r}-0.0019 \\
(-1.34)\end{array}$ & $\begin{array}{r}-0.0013 \\
(-1.09)\end{array}$ & $\begin{array}{r}-0.0008 \\
(-0.65)\end{array}$ & $\begin{array}{r}-0.0017 \\
(-1.71)\end{array}$ & $\begin{array}{r}-0.0015 \\
(-1.49)\end{array}$ & $\begin{array}{r}-0.0014 \\
(-1.37)\end{array}$ & $\begin{array}{r}-0.0014 \\
(-1.33)\end{array}$ & $\begin{array}{r}-0.0016 \\
(-1.54)\end{array}$ & $\begin{array}{r}-0.0014 \\
(-1.31)\end{array}$ & $\begin{array}{r}-0.0016 \\
(-1.58)\end{array}$ & $\begin{array}{r}-0.0014 \\
(-1.41)\end{array}$ & $\begin{array}{r}-0.0014 \\
(-1.40)\end{array}$ & $\begin{array}{r}-0.0014 \\
(-1.33)\end{array}$ & $\begin{array}{r}-0.0014 \\
(-1.38)\end{array}$ & $\begin{array}{r}-0.0014 \\
(-1.41)\end{array}$ & $\begin{array}{r}-0.0013 \\
(-1.24)\end{array}$ \\
\hline$\lambda_{\mathrm{IVol}}$ & $\begin{array}{r}0.0629 \\
(1.23)\end{array}$ & $\begin{array}{r}0.0446 \\
(1.01)\end{array}$ & $\begin{array}{r}0.0046 \\
(0.11)\end{array}$ & $\begin{array}{r}0.0110 \\
(0.30)\end{array}$ & $\begin{array}{r}-0.0003 \\
(-0.01)\end{array}$ & $\begin{array}{r}-0.0026 \\
(-0.07)\end{array}$ & $\begin{array}{r}-0.0044 \\
(-0.12)\end{array}$ & $\begin{array}{r}-0.0112 \\
(-0.31)\end{array}$ & $\begin{array}{r}-0.0121 \\
(-0.34)\end{array}$ & $\begin{array}{r}-0.0151 \\
(-0.42)\end{array}$ & $\begin{array}{r}-0.0178 \\
(-0.50)\end{array}$ & $\begin{array}{r}-0.0207 \\
(-0.58)\end{array}$ & $\begin{array}{r}-0.0230 \\
(-0.64)\end{array}$ & $\begin{array}{r}-0.0226 \\
(-0.63)\end{array}$ & $\begin{array}{r}-0.0197 \\
(-0.55)\end{array}$ & $\begin{array}{r}-0.0410 \\
(-1.20)\end{array}$ \\
\hline \multicolumn{2}{|c|}{ Panel B: $\lambda_{\text {IVoI }}(20)-\lambda_{\text {IVoI }}(N)$} & $\begin{array}{r}0.0176 \\
(0.96)\end{array}$ & $\begin{array}{r}0.0576 \\
(2.48)\end{array}$ & $\begin{array}{r}0.0511 \\
(1.74)\end{array}$ & $\begin{array}{r}0.0624 \\
(1.93)\end{array}$ & $\begin{array}{r}0.0648 \\
(1.94)\end{array}$ & $\begin{array}{r}0.0665 \\
(1.96)\end{array}$ & $\begin{array}{r}0.0733 \\
(2.13)\end{array}$ & $\begin{array}{r}0.0743 \\
(2.11)\end{array}$ & $\begin{array}{r}0.0772 \\
(2.17)\end{array}$ & $\begin{array}{r}0.0799 \\
(2.23)\end{array}$ & $\begin{array}{r}0.0828 \\
(2.32)\end{array}$ & $\begin{array}{r}0.0851 \\
(2.35)\end{array}$ & $\begin{array}{r}0.0847 \\
(2.34)\end{array}$ & $\begin{array}{r}0.0818 \\
(2.24)\end{array}$ & $\begin{array}{r}0.1031 \\
(2.80)\end{array}$ \\
\hline
\end{tabular}




\section{Table 3: Pricing of idiosyncratic volatility within a liquidity-augmented Carhart model}

The table presents averages for the prices of risk associated with the four factors of Carhart (1997) augmented with the liquidity risk premium of Pastor and Stambaugh (2003) and the price of idiosyncratic volatility. The prices of risk are estimated from the second-step of Fama and MacBeth (1973) regressions over the period January 1973 - December 2011. $N$ is the maximum number of stocks included in the portfolios, ALL means that the 100 Fama and French (1992) portfolios were considered in the cross-sectional regressions. $\lambda_{\text {IVol }}(20)-\lambda_{\text {IVol }}(N)$ measures the difference in the prices of idiosyncratic volatility for the portfolio with 20 stocks and the portfolio with $N$ stocks. $t$-statistics are in parentheses.

\begin{tabular}{|c|c|c|c|c|c|c|c|c|c|c|c|c|c|c|c|c|}
\hline$N<=$ & 20 & 25 & 30 & 40 & 50 & 60 & 70 & 80 & 90 & 100 & 120 & 140 & 160 & 180 & 200 & ALL \\
\hline \multicolumn{17}{|c|}{ Panel A: Estimated prices of risk } \\
\hline$\lambda_{0}$ & $\begin{array}{r}0.0026 \\
(1.04)\end{array}$ & $\begin{array}{r}0.0032 \\
(1.41)\end{array}$ & $\begin{array}{r}0.0042 \\
(1.93)\end{array}$ & $\begin{array}{r}0.0046 \\
(2.19)\end{array}$ & $\begin{array}{r}0.0045 \\
(2.24)\end{array}$ & $\begin{array}{r}0.0052 \\
(2.64)\end{array}$ & $\begin{array}{r}0.0052 \\
(2.64)\end{array}$ & $\begin{array}{r}0.0055 \\
(2.82)\end{array}$ & $\begin{array}{r}0.0057 \\
(2.98)\end{array}$ & $\begin{array}{r}0.0061 \\
(3.16)\end{array}$ & $\begin{array}{r}0.0063 \\
(3.26)\end{array}$ & $\begin{array}{r}0.0065 \\
(3.42)\end{array}$ & $\begin{array}{r}0.0067 \\
(3.54)\end{array}$ & $\begin{array}{r}0.0067 \\
(3.55)\end{array}$ & $\begin{array}{r}0.0066 \\
(3.52)\end{array}$ & $\begin{array}{r}0.0078 \\
(4.29)\end{array}$ \\
\hline$\lambda_{\mathrm{M}}$ & $\begin{array}{r}0.0012 \\
(0.66)\end{array}$ & $\begin{array}{r}0.0011 \\
(0.72)\end{array}$ & $\begin{array}{r}0.0008 \\
(0.59)\end{array}$ & $\begin{array}{r}0.0005 \\
(0.42)\end{array}$ & $\begin{array}{r}0.0008 \\
(0.62)\end{array}$ & $\begin{array}{r}0.0002 \\
(0.19)\end{array}$ & $\begin{array}{r}0.0001 \\
(0.05)\end{array}$ & $\begin{array}{r}-0.0003 \\
(-0.21)\end{array}$ & $\begin{array}{r}-0.0003 \\
(-0.22)\end{array}$ & $\begin{array}{r}-0.0006 \\
(-0.49)\end{array}$ & $\begin{array}{r}-0.0008 \\
(-0.62)\end{array}$ & $\begin{array}{r}-0.0011 \\
(-0.88)\end{array}$ & $\begin{array}{r}-0.0011 \\
(-0.92)\end{array}$ & $\begin{array}{r}-0.0011 \\
(-0.88)\end{array}$ & $\begin{array}{r}-0.0011 \\
(-0.85)\end{array}$ & $\begin{array}{r}-0.0017 \\
(-1.29)\end{array}$ \\
\hline$\lambda_{\mathrm{SMB}}$ & $\begin{array}{r}0.0037 \\
(2.72)\end{array}$ & $\begin{array}{r}0.0030 \\
(2.22)\end{array}$ & $\begin{array}{r}0.0024 \\
(1.87)\end{array}$ & $\begin{array}{r}0.0021 \\
(1.77)\end{array}$ & $\begin{array}{r}0.0020 \\
(1.66)\end{array}$ & $\begin{array}{r}0.0020 \\
(1.57)\end{array}$ & $\begin{array}{r}0.0018 \\
(1.45)\end{array}$ & $\begin{array}{r}0.0017 \\
(1.38)\end{array}$ & $\begin{array}{r}0.0018 \\
(1.41)\end{array}$ & $\begin{array}{r}0.0018 \\
(1.39)\end{array}$ & $\begin{array}{r}0.0016 \\
(1.31)\end{array}$ & $\begin{array}{r}0.0016 \\
(1.26)\end{array}$ & $\begin{array}{r}0.0015 \\
(1.20)\end{array}$ & $\begin{array}{r}0.0015 \\
(1.18)\end{array}$ & $\begin{array}{r}0.0014 \\
(1.12)\end{array}$ & $\begin{array}{r}0.0013 \\
(1.00)\end{array}$ \\
\hline$\lambda_{\mathrm{HML}}$ & $\begin{array}{r}0.0021 \\
(1.64)\end{array}$ & $\begin{array}{r}0.0025 \\
(2.20)\end{array}$ & $\begin{array}{r}0.0028 \\
(2.45)\end{array}$ & $\begin{array}{r}0.0024 \\
(2.14)\end{array}$ & $\begin{array}{r}0.0026 \\
(2.21)\end{array}$ & $\begin{array}{r}0.0027 \\
(2.17)\end{array}$ & $\begin{array}{r}0.0031 \\
(2.47)\end{array}$ & $\begin{array}{r}0.0032 \\
(2.59)\end{array}$ & $\begin{array}{r}0.0033 \\
(2.62)\end{array}$ & $\begin{array}{r}0.0033 \\
(2.68)\end{array}$ & $\begin{array}{r}0.0036 \\
(2.83)\end{array}$ & $\begin{array}{r}0.0036 \\
(2.86)\end{array}$ & $\begin{array}{r}0.0037 \\
(2.91)\end{array}$ & $\begin{array}{r}0.0037 \\
(2.96)\end{array}$ & $\begin{array}{r}0.0037 \\
(2.95)\end{array}$ & $\begin{array}{r}0.0040 \\
(3.11)\end{array}$ \\
\hline$\lambda_{\text {Mom }}$ & $\begin{array}{r}-0.0019 \\
(-1.36)\end{array}$ & $\begin{array}{r}-0.0014 \\
(-1.16)\end{array}$ & $\begin{array}{r}-0.0009 \\
(-0.76)\end{array}$ & $\begin{array}{r}-0.0018 \\
(-1.70)\end{array}$ & $\begin{array}{r}-0.0015 \\
(-1.43)\end{array}$ & $\begin{array}{r}-0.0015 \\
(-1.50)\end{array}$ & $\begin{array}{r}-0.0015 \\
(-1.40)\end{array}$ & $\begin{array}{r}-0.0016 \\
(-1.58)\end{array}$ & $\begin{array}{r}-0.0015 \\
(-1.43)\end{array}$ & $\begin{array}{r}-0.0016 \\
(-1.50)\end{array}$ & $\begin{array}{r}-0.0016 \\
(-1.54)\end{array}$ & $\begin{array}{r}-0.0014 \\
(-1.40)\end{array}$ & $\begin{array}{r}-0.0015 \\
(-1.46)\end{array}$ & $\begin{array}{r}-0.0015 \\
(-1.45)\end{array}$ & $\begin{array}{r}-0.0015 \\
(-1.43)\end{array}$ & $\begin{array}{r}-0.0014 \\
(-1.38)\end{array}$ \\
\hline$\lambda_{\mathrm{LRP}}$ & $\begin{array}{r}0.0005 \\
(0.39)\end{array}$ & $\begin{array}{r}0.0015 \\
(1.20)\end{array}$ & $\begin{array}{r}0.0016 \\
(1.45)\end{array}$ & $\begin{array}{r}0.0021 \\
(2.23)\end{array}$ & $\begin{array}{r}0.0028 \\
(2.96)\end{array}$ & $\begin{array}{r}0.0027 \\
(2.93)\end{array}$ & $\begin{array}{r}0.0030 \\
(3.22)\end{array}$ & $\begin{array}{r}0.0032 \\
(3.48)\end{array}$ & $\begin{array}{r}0.0031 \\
(3.37)\end{array}$ & $\begin{array}{r}0.0029 \\
(3.25)\end{array}$ & $\begin{array}{r}0.0031 \\
(3.40)\end{array}$ & $\begin{array}{r}0.0031 \\
(3.42)\end{array}$ & $\begin{array}{r}0.0031 \\
(3.49)\end{array}$ & $\begin{array}{r}0.0030 \\
(3.29)\end{array}$ & $\begin{array}{r}0.0031 \\
(3.49)\end{array}$ & $\begin{array}{r}0.0033 \\
(3.47)\end{array}$ \\
\hline$\lambda_{\mathrm{IVol}}$ & $\begin{array}{r}0.0635 \\
(1.25)\end{array}$ & $\begin{array}{r}0.0389 \\
(0.88)\end{array}$ & $\begin{array}{r}0.0008 \\
(0.02)\end{array}$ & $\begin{array}{r}0.0104 \\
(0.28)\end{array}$ & $\begin{array}{r}-0.0023 \\
(-0.06)\end{array}$ & $\begin{array}{r}-0.0069 \\
(-0.19)\end{array}$ & $\begin{array}{r}-0.0045 \\
(-0.12)\end{array}$ & $\begin{array}{r}-0.0071 \\
(-0.20)\end{array}$ & $\begin{array}{r}-0.0157 \\
(-0.44)\end{array}$ & $\begin{array}{r}-0.0175 \\
(-0.49)\end{array}$ & $\begin{array}{r}-0.0194 \\
(-0.55)\end{array}$ & $\begin{array}{r}-0.0170 \\
(-0.48)\end{array}$ & $\begin{array}{r}-0.0239 \\
(-0.67)\end{array}$ & $\begin{array}{r}-0.0244 \\
(-0.69)\end{array}$ & $\begin{array}{r}-0.0202 \\
(-0.57)\end{array}$ & $\begin{array}{r}-0.0477 \\
(-1.38)\end{array}$ \\
\hline \multicolumn{2}{|c|}{ Panel B: $\lambda_{\text {IVoI }}(20)-\lambda_{I V o I}(N)$} & $\begin{array}{r}0.0264 \\
(1.37)\end{array}$ & $\begin{array}{r}0.0645 \\
(2.68)\end{array}$ & $\begin{array}{r}0.0549 \\
(1.84)\end{array}$ & $\begin{array}{r}0.0676 \\
(2.07)\end{array}$ & $\begin{array}{r}0.0722 \\
(2.13)\end{array}$ & $\begin{array}{r}0.0698 \\
(2.02)\end{array}$ & $\begin{array}{r}0.0724 \\
(2.05)\end{array}$ & $\begin{array}{r}0.0810 \\
(2.27)\end{array}$ & $\begin{array}{r}0.0828 \\
(2.28)\end{array}$ & $\begin{array}{r}0.0847 \\
(2.31)\end{array}$ & $\begin{array}{r}0.0823 \\
(2.23)\end{array}$ & $\begin{array}{r}0.0892 \\
(2.42)\end{array}$ & $\begin{array}{r}0.0897 \\
(2.42)\end{array}$ & $\begin{array}{r}0.0855 \\
(2.30)\end{array}$ & $\begin{array}{r}0.1130 \\
(2.99)\end{array}$ \\
\hline
\end{tabular}


Table 4: Pricing of idiosyncratic volatility within a liquidity and reversals-augmented Carhart model

The table presents averages for the prices of risk associated with $i$ ) the four factors of Carhart (1997), ii) the liquidity risk premium of Pastor and Stambaugh (2003), iii) the portfolios formed on short and long-term reversals and iv) idiosyncratic volatility. The prices of risk are estimated from the second-step of Fama and MacBeth (1973) regressions over the period January 1973 - December $2011 . N$ is the maximum number of stocks included in the portfolios, ALL means that the 100 Fama and French (1992) portfolios were considered in the cross-sectional regressions. $\lambda_{\mathrm{IVol}}(20)-\lambda_{\mathrm{IVol}}(N)$ measures the difference in the prices of idiosyncratic volatility for the portfolio with 20 stocks and the portfolio with $N$ stocks. $t$-statistics are in parentheses. 


\begin{tabular}{|c|c|c|c|c|c|c|c|c|c|c|c|c|c|c|c|c|}
\hline$N<=$ & 20 & 25 & 30 & 40 & 50 & 60 & 70 & 80 & 90 & 100 & 120 & 140 & 160 & 180 & 200 & ALL \\
\hline \multicolumn{17}{|c|}{ Panel A: Estimated prices of risk } \\
\hline$\lambda_{0}$ & $\begin{array}{r}0.0031 \\
(1.23)\end{array}$ & $\begin{array}{r}0.0037 \\
(1.65)\end{array}$ & $\begin{array}{r}0.0045 \\
(2.08)\end{array}$ & $\begin{array}{r}0.0048 \\
(2.30)\end{array}$ & $\begin{array}{r}0.0048 \\
(2.42)\end{array}$ & $\begin{array}{r}0.0050 \\
(2.54)\end{array}$ & $\begin{array}{r}0.0054 \\
(2.76)\end{array}$ & $\begin{array}{r}0.0058 \\
(2.99)\end{array}$ & $\begin{array}{r}0.0059 \\
(3.09)\end{array}$ & $\begin{array}{r}0.0062 \\
(3.24)\end{array}$ & $\begin{array}{r}0.0067 \\
(3.52)\end{array}$ & $\begin{array}{r}0.0068 \\
(3.56)\end{array}$ & $\begin{array}{r}0.0069 \\
(3.68)\end{array}$ & $\begin{array}{r}0.0070 \\
(3.70)\end{array}$ & $\begin{array}{r}0.0068 \\
(3.69)\end{array}$ & $\begin{array}{r}0.0079 \\
(4.39)\end{array}$ \\
\hline$\lambda_{\mathrm{M}}$ & $\begin{array}{r}0.0009 \\
(0.49)\end{array}$ & $\begin{array}{r}0.0004 \\
(0.27)\end{array}$ & $\begin{array}{r}0.0008 \\
(0.56)\end{array}$ & $\begin{array}{r}0.0005 \\
(0.39)\end{array}$ & $\begin{array}{r}0.0006 \\
(0.45)\end{array}$ & $\begin{array}{r}0.0004 \\
(0.34)\end{array}$ & $\begin{array}{r}-0.0001 \\
(-0.06)\end{array}$ & $\begin{array}{r}-0.0004 \\
(-0.32)\end{array}$ & $\begin{array}{r}-0.0005 \\
(-0.37)\end{array}$ & $\begin{array}{r}-0.0007 \\
(-0.59)\end{array}$ & $\begin{array}{r}-0.0010 \\
(-0.85)\end{array}$ & $\begin{array}{r}-0.0012 \\
(-1.02)\end{array}$ & $\begin{array}{r}-0.0013 \\
(-1.09)\end{array}$ & $\begin{array}{r}-0.0014 \\
(-1.12)\end{array}$ & $\begin{array}{r}-0.0012 \\
(-1.00)\end{array}$ & $\begin{array}{r}-0.0019 \\
(-1.46)\end{array}$ \\
\hline$\lambda_{\mathrm{SMB}}$ & $\begin{array}{r}0.0036 \\
(2.70)\end{array}$ & $\begin{array}{r}0.0029 \\
(2.21)\end{array}$ & $\begin{array}{r}0.0023 \\
(1.87)\end{array}$ & $\begin{array}{r}0.0022 \\
(1.84)\end{array}$ & $\begin{array}{r}0.0021 \\
(1.72)\end{array}$ & $\begin{array}{r}0.0020 \\
(1.63)\end{array}$ & $\begin{array}{r}0.0018 \\
(1.44)\end{array}$ & $\begin{array}{r}0.0017 \\
(1.39)\end{array}$ & $\begin{array}{r}0.0018 \\
(1.40)\end{array}$ & $\begin{array}{r}0.0018 \\
(1.40)\end{array}$ & $\begin{array}{r}0.0017 \\
(1.32)\end{array}$ & $\begin{array}{r}0.0016 \\
(1.28)\end{array}$ & $\begin{array}{r}0.0015 \\
(1.21)\end{array}$ & $\begin{array}{r}0.0015 \\
(1.19)\end{array}$ & $\begin{array}{r}0.0015 \\
(1.14)\end{array}$ & $\begin{array}{r}0.0013 \\
(1.01)\end{array}$ \\
\hline$\lambda_{\mathrm{HML}}$ & $\begin{array}{r}0.0019 \\
(1.51)\end{array}$ & $\begin{array}{r}0.0025 \\
(2.29)\end{array}$ & $\begin{array}{r}0.0026 \\
(2.37)\end{array}$ & $\begin{array}{r}0.0024 \\
(2.12)\end{array}$ & $\begin{array}{r}0.0026 \\
(2.17)\end{array}$ & $\begin{array}{r}0.0026 \\
(2.12)\end{array}$ & $\begin{array}{r}0.0031 \\
(2.46)\end{array}$ & $\begin{array}{r}0.0032 \\
(2.60)\end{array}$ & $\begin{array}{r}0.0033 \\
(2.64)\end{array}$ & $\begin{array}{r}0.0033 \\
(2.69)\end{array}$ & $\begin{array}{r}0.0036 \\
(2.85)\end{array}$ & $\begin{array}{r}0.0037 \\
(2.90)\end{array}$ & $\begin{array}{r}0.0037 \\
(2.96)\end{array}$ & $\begin{array}{r}0.0037 \\
(2.95)\end{array}$ & $\begin{array}{r}0.0038 \\
(2.98)\end{array}$ & $\begin{array}{r}0.0040 \\
(3.17)\end{array}$ \\
\hline$\lambda_{\text {Mom }}$ & $\begin{array}{r}-0.0017 \\
(-1.28)\end{array}$ & $\begin{array}{r}-0.0015 \\
(-1.23)\end{array}$ & $\begin{array}{r}-0.0009 \\
(-0.81)\end{array}$ & $\begin{array}{r}-0.0018 \\
(-1.74)\end{array}$ & $\begin{array}{r}-0.0015 \\
(-1.52)\end{array}$ & $\begin{array}{r}-0.0016 \\
(-1.60)\end{array}$ & $\begin{array}{r}-0.0016 \\
(-1.55)\end{array}$ & $\begin{array}{r}-0.0017 \\
(-1.64)\end{array}$ & $\begin{array}{r}-0.0016 \\
(-1.62)\end{array}$ & $\begin{array}{r}-0.0018 \\
(-1.71)\end{array}$ & $\begin{array}{r}-0.0016 \\
(-1.59)\end{array}$ & $\begin{array}{r}-0.0015 \\
(-1.46)\end{array}$ & $\begin{array}{r}-0.0016 \\
(-1.60)\end{array}$ & $\begin{array}{r}-0.0016 \\
(-1.60)\end{array}$ & $\begin{array}{r}-0.0017 \\
(-1.66)\end{array}$ & $\begin{array}{r}-0.0013 \\
(-1.32)\end{array}$ \\
\hline$\lambda_{\mathrm{LRP}}$ & $\begin{array}{r}0.0004 \\
(0.32)\end{array}$ & $\begin{array}{r}0.0013 \\
(1.08)\end{array}$ & $\begin{array}{r}0.0011 \\
(1.02)\end{array}$ & $\begin{array}{r}0.0019 \\
(2.01)\end{array}$ & $\begin{array}{r}0.0023 \\
(2.52)\end{array}$ & $\begin{array}{r}0.0024 \\
(2.66)\end{array}$ & $\begin{array}{r}0.0027 \\
(2.92)\end{array}$ & $\begin{array}{r}0.0030 \\
(3.35)\end{array}$ & $\begin{array}{r}0.0028 \\
(3.08)\end{array}$ & $\begin{array}{r}0.0027 \\
(3.05)\end{array}$ & $\begin{array}{r}0.0029 \\
(3.31)\end{array}$ & $\begin{array}{r}0.0029 \\
(3.26)\end{array}$ & $\begin{array}{r}0.0027 \\
(3.01)\end{array}$ & $\begin{array}{r}0.0029 \\
(3.23)\end{array}$ & $\begin{array}{r}0.0028 \\
(3.22)\end{array}$ & $\begin{array}{r}0.0030 \\
(3.24)\end{array}$ \\
\hline$\lambda_{\mathrm{ST}} \mathrm{Rev}$ & $\begin{array}{r}0.0015 \\
(1.49)\end{array}$ & $\begin{array}{r}0.0012 \\
(1.34)\end{array}$ & $\begin{array}{r}0.0010 \\
(1.29)\end{array}$ & $\begin{array}{r}0.0012 \\
(1.69)\end{array}$ & $\begin{array}{r}0.0010 \\
(1.29)\end{array}$ & $\begin{array}{r}0.0013 \\
(1.66)\end{array}$ & $\begin{array}{r}0.0013 \\
(1.70)\end{array}$ & $\begin{array}{r}0.0012 \\
(1.57)\end{array}$ & $\begin{array}{r}0.0012 \\
(1.57)\end{array}$ & $\begin{array}{r}0.0012 \\
(1.59)\end{array}$ & $\begin{array}{r}0.0011 \\
(1.39)\end{array}$ & $\begin{array}{r}0.0010 \\
(1.42)\end{array}$ & $\begin{array}{r}0.0010 \\
(1.35)\end{array}$ & $\begin{array}{r}0.0010 \\
(1.35)\end{array}$ & $\begin{array}{r}0.0010 \\
(1.37)\end{array}$ & $\begin{array}{r}0.0012 \\
(1.60)\end{array}$ \\
\hline$\lambda_{\mathrm{LT} \_\mathrm{Rev}}$ & $\begin{array}{r}0.0016 \\
(1.75)\end{array}$ & $\begin{array}{r}0.0018 \\
(2.21)\end{array}$ & $\begin{array}{r}0.0019 \\
(2.43)\end{array}$ & $\begin{array}{r}0.0016 \\
(2.19)\end{array}$ & $\begin{array}{r}0.0018 \\
(2.50)\end{array}$ & $\begin{array}{r}0.0018 \\
(2.38)\end{array}$ & $\begin{array}{r}0.0018 \\
(2.37)\end{array}$ & $\begin{array}{r}0.0019 \\
(2.59)\end{array}$ & $\begin{array}{r}0.0021 \\
(2.77)\end{array}$ & $\begin{array}{r}0.0020 \\
(2.75)\end{array}$ & $\begin{array}{r}0.0022 \\
(3.03)\end{array}$ & $\begin{array}{r}0.0023 \\
(3.05)\end{array}$ & $\begin{array}{r}0.0022 \\
(3.02)\end{array}$ & $\begin{array}{r}0.0022 \\
(2.92)\end{array}$ & $\begin{array}{r}0.0022 \\
(2.93)\end{array}$ & $\begin{array}{r}0.0025 \\
(3.23)\end{array}$ \\
\hline$\lambda_{\text {IVol }}$ & $\begin{array}{r}0.0658 \\
(1.27)\end{array}$ & $\begin{array}{r}0.0499 \\
(1.10)\end{array}$ & $\begin{array}{r}-0.0035 \\
(-0.08)\end{array}$ & $\begin{array}{r}0.0070 \\
(0.18)\end{array}$ & $\begin{array}{r}-0.0044 \\
(-0.12)\end{array}$ & $\begin{array}{r}-0.0011 \\
(-0.03)\end{array}$ & $\begin{array}{r}-0.0031 \\
(-0.09)\end{array}$ & $\begin{array}{r}-0.0114 \\
(-0.32)\end{array}$ & $\begin{array}{r}-0.0158 \\
(-0.44)\end{array}$ & $\begin{array}{r}-0.0154 \\
(-0.43)\end{array}$ & $\begin{array}{r}-0.0261 \\
(-0.72)\end{array}$ & $\begin{array}{r}-0.0205 \\
(-0.56)\end{array}$ & $\begin{array}{r}-0.0250 \\
(-0.68)\end{array}$ & $\begin{array}{r}-0.0225 \\
(-0.62)\end{array}$ & $\begin{array}{r}-0.0239 \\
(-0.66)\end{array}$ & $\begin{array}{r}-0.0471 \\
(-1.33)\end{array}$ \\
\hline \multicolumn{2}{|c|}{ Panel B: $\lambda_{\text {IVoI }}(20)-\lambda_{\text {IVol }}(N)$} & $\begin{array}{r}0.0101 \\
(0.51) \\
\end{array}$ & $\begin{array}{r}0.0635 \\
(2.64) \\
\end{array}$ & $\begin{array}{r}0.0531 \\
(1.74) \\
\end{array}$ & $\begin{array}{r}0.0644 \\
(1.91) \\
\end{array}$ & $\begin{array}{r}0.0611 \\
(1.75) \\
\end{array}$ & $\begin{array}{r}0.0631 \\
(1.77) \\
\end{array}$ & $\begin{array}{r}0.0714 \\
(1.98) \\
\end{array}$ & $\begin{array}{r}0.0758 \\
(2.06) \\
\end{array}$ & $\begin{array}{r}0.0754 \\
(2.01) \\
\end{array}$ & $\begin{array}{r}0.0861 \\
(2.25) \\
\end{array}$ & $\begin{array}{r}0.0805 \\
(2.11) \\
\end{array}$ & $\begin{array}{r}0.0850 \\
(2.21) \\
\end{array}$ & $\begin{array}{r}0.0825 \\
(2.16) \\
\end{array}$ & $\begin{array}{r}0.0839 \\
(2.17) \\
\end{array}$ & $\begin{array}{r}0.1071 \\
(2.74) \\
\end{array}$ \\
\hline
\end{tabular}

\section{Table 5: Pricing of idiosyncratic volatility within a VIX, liquidity and reversals-augmented Carhart model}

The table presents averages for the prices of risk associated with $i$ ) the four factors of Carhart (1997), ii) the liquidity risk premium of Pastor and Stambaugh (2003), iii) the portfolios formed on short and long-term reversals, $i v$ ) VIX and $v$ ) idiosyncratic volatility. The prices of risk are estimated from the second-step of Fama and MacBeth (1973) regressions over the period January 1973 - December 2011. $N$ is the maximum number of stocks included in the portfolios, ALL means that the 100 Fama and French (1992) portfolios were considered in the cross-sectional 
regressions. $\lambda_{\mathrm{IVol}}(20)-\lambda_{\mathrm{IVol}}(N)$ measures the difference in the prices of idiosyncratic volatility for the portfolio with 20 stocks and the portfolio with $N$ stocks. $t$-statistics are in parentheses.

\begin{tabular}{|c|c|c|c|c|c|c|c|c|c|c|c|c|c|c|c|c|}
\hline$N<=$ & 20 & 25 & 30 & 40 & 50 & 60 & 70 & 80 & 90 & 100 & 120 & 140 & 160 & 180 & 200 & ALL \\
\hline \multicolumn{17}{|c|}{ Panel A: Estimated prices of risk } \\
\hline$\lambda_{0}$ & $\begin{array}{r}0.0030 \\
(0.86)\end{array}$ & $\begin{array}{r}0.0037 \\
(1.14)\end{array}$ & $\begin{array}{r}0.0050 \\
(1.58)\end{array}$ & $\begin{array}{r}0.0051 \\
(1.71)\end{array}$ & $\begin{array}{r}0.0050 \\
(1.77)\end{array}$ & $\begin{array}{r}0.0052 \\
(1.90)\end{array}$ & $\begin{array}{r}0.0059 \\
(2.13)\end{array}$ & $\begin{array}{r}0.0063 \\
(2.33)\end{array}$ & $\begin{array}{r}0.0065 \\
(2.45)\end{array}$ & $\begin{array}{r}0.0066 \\
(2.49)\end{array}$ & $\begin{array}{r}0.0073 \\
(2.72)\end{array}$ & $\begin{array}{r}0.0073 \\
(2.72)\end{array}$ & $\begin{array}{r}0.0075 \\
(2.80)\end{array}$ & $\begin{array}{r}0.0078 \\
(2.98)\end{array}$ & $\begin{array}{r}0.0077 \\
(2.96)\end{array}$ & $\begin{array}{r}0.0093 \\
(3.76)\end{array}$ \\
\hline$\lambda_{\mathrm{M}}$ & $\begin{array}{r}0.0007 \\
(0.30)\end{array}$ & $\begin{array}{r}0.0004 \\
(0.16)\end{array}$ & $\begin{array}{l}0.0000 \\
(-0.01)\end{array}$ & $\begin{array}{r}0.0003 \\
(0.19)\end{array}$ & $\begin{array}{r}0.0005 \\
(0.30)\end{array}$ & $\begin{array}{r}0.0003 \\
(0.18)\end{array}$ & $\begin{array}{r}-0.0002 \\
(-0.11)\end{array}$ & $\begin{array}{r}-0.0006 \\
(-0.36)\end{array}$ & $\begin{array}{r}-0.0006 \\
(-0.34)\end{array}$ & $\begin{array}{r}-0.0005 \\
(-0.30)\end{array}$ & $\begin{array}{r}-0.0011 \\
(-0.64)\end{array}$ & $\begin{array}{r}-0.0010 \\
(-0.60)\end{array}$ & $\begin{array}{r}-0.0011 \\
(-0.63)\end{array}$ & $\begin{array}{r}-0.0015 \\
(-0.90)\end{array}$ & $\begin{array}{r}-0.0015 \\
(-0.86)\end{array}$ & $\begin{array}{r}-0.0022 \\
(-1.23)\end{array}$ \\
\hline$\lambda_{\mathrm{SMB}}$ & $\begin{array}{r}0.0040 \\
(1.92)\end{array}$ & $\begin{array}{r}0.0036 \\
(1.76)\end{array}$ & $\begin{array}{r}0.0026 \\
(1.37)\end{array}$ & $\begin{array}{r}0.0021 \\
(1.20)\end{array}$ & $\begin{array}{r}0.0019 \\
(1.03)\end{array}$ & $\begin{array}{r}0.0018 \\
(0.96)\end{array}$ & $\begin{array}{r}0.0014 \\
(0.77)\end{array}$ & $\begin{array}{r}0.0013 \\
(0.72)\end{array}$ & $\begin{array}{r}0.0014 \\
(0.73)\end{array}$ & $\begin{array}{r}0.0015 \\
(0.76)\end{array}$ & $\begin{array}{r}0.0013 \\
(0.67)\end{array}$ & $\begin{array}{r}0.0014 \\
(0.68)\end{array}$ & $\begin{array}{r}0.0012 \\
(0.61)\end{array}$ & $\begin{array}{r}0.0012 \\
(0.61)\end{array}$ & $\begin{array}{r}0.0011 \\
(0.56)\end{array}$ & $\begin{array}{r}0.0011 \\
(0.54)\end{array}$ \\
\hline$\lambda_{\mathrm{HML}}$ & $\begin{array}{r}0.0019 \\
(1.06)\end{array}$ & $\begin{array}{r}0.0023 \\
(1.52)\end{array}$ & $\begin{array}{r}0.0026 \\
(1.64)\end{array}$ & $\begin{array}{r}0.0014 \\
(0.90)\end{array}$ & $\begin{array}{r}0.0017 \\
(0.96)\end{array}$ & $\begin{array}{r}0.0017 \\
(0.95)\end{array}$ & $\begin{array}{r}0.0022 \\
(1.18)\end{array}$ & $\begin{array}{r}0.0025 \\
(1.30)\end{array}$ & $\begin{array}{r}0.0025 \\
(1.31)\end{array}$ & $\begin{array}{r}0.0025 \\
(1.32)\end{array}$ & $\begin{array}{r}0.0029 \\
(1.52)\end{array}$ & $\begin{array}{r}0.0030 \\
(1.54)\end{array}$ & $\begin{array}{r}0.0031 \\
(1.62)\end{array}$ & $\begin{array}{r}0.0032 \\
(1.66)\end{array}$ & $\begin{array}{r}0.0032 \\
(1.66)\end{array}$ & $\begin{array}{r}0.0036 \\
(1.86)\end{array}$ \\
\hline$\lambda_{\text {Mom }}$ & $\begin{array}{r}-0.0005 \\
(-0.26)\end{array}$ & $\begin{array}{r}-0.0009 \\
(-0.51)\end{array}$ & $\begin{array}{r}0.0004 \\
(0.19)\end{array}$ & $\begin{array}{r}-0.0012 \\
(-0.77)\end{array}$ & $\begin{array}{r}-0.0011 \\
(-0.67)\end{array}$ & $\begin{array}{r}-0.0008 \\
(-0.49)\end{array}$ & $\begin{array}{r}-0.0010 \\
(-0.60)\end{array}$ & $\begin{array}{r}-0.0014 \\
(-0.93)\end{array}$ & $\begin{array}{r}-0.0011 \\
(-0.65)\end{array}$ & $\begin{array}{r}-0.0009 \\
(-0.60)\end{array}$ & $\begin{array}{r}-0.0008 \\
(-0.50)\end{array}$ & $\begin{array}{r}-0.0009 \\
(-0.56)\end{array}$ & $\begin{array}{r}-0.0008 \\
(-0.49)\end{array}$ & $\begin{array}{r}-0.0007 \\
(-0.46)\end{array}$ & $\begin{array}{r}-0.0008 \\
(-0.53)\end{array}$ & $\begin{array}{r}-0.0003 \\
(-0.18)\end{array}$ \\
\hline$\lambda_{\mathrm{LRP}}$ & $\begin{array}{r}0.0016 \\
(0.75)\end{array}$ & $\begin{array}{r}0.0023 \\
(1.22)\end{array}$ & $\begin{array}{r}0.0018 \\
(1.06)\end{array}$ & $\begin{array}{r}0.0028 \\
(1.79)\end{array}$ & $\begin{array}{r}0.0038 \\
(2.45)\end{array}$ & $\begin{array}{r}0.0038 \\
(2.56)\end{array}$ & $\begin{array}{r}0.0042 \\
(2.93)\end{array}$ & $\begin{array}{r}0.0044 \\
(3.12)\end{array}$ & $\begin{array}{r}0.0041 \\
(2.87)\end{array}$ & $\begin{array}{r}0.0041 \\
(2.95)\end{array}$ & $\begin{array}{r}0.0041 \\
(2.85)\end{array}$ & $\begin{array}{r}0.0040 \\
(2.81)\end{array}$ & $\begin{array}{r}0.0039 \\
(2.76)\end{array}$ & $\begin{array}{r}0.0039 \\
(2.80)\end{array}$ & $\begin{array}{r}0.0038 \\
(2.66)\end{array}$ & $\begin{array}{r}0.0043 \\
(2.88)\end{array}$ \\
\hline$\lambda_{\text {ST_Rev }}$ & $\begin{array}{r}0.0025 \\
(1.64)\end{array}$ & $\begin{array}{r}0.0023 \\
(1.65)\end{array}$ & $\begin{array}{r}0.0015 \\
(1.21)\end{array}$ & $\begin{array}{r}0.0013 \\
(1.19)\end{array}$ & $\begin{array}{r}0.0011 \\
(0.90)\end{array}$ & $\begin{array}{r}0.0014 \\
(1.16)\end{array}$ & $\begin{array}{r}0.0015 \\
(1.20)\end{array}$ & $\begin{array}{r}0.0014 \\
(1.13)\end{array}$ & $\begin{array}{r}0.0012 \\
(0.99)\end{array}$ & $\begin{array}{r}0.0013 \\
(1.09)\end{array}$ & $\begin{array}{r}0.0011 \\
(0.93)\end{array}$ & $\begin{array}{r}0.0011 \\
(0.89)\end{array}$ & $\begin{array}{r}0.0008 \\
(0.68)\end{array}$ & $\begin{array}{r}0.0006 \\
(0.52)\end{array}$ & $\begin{array}{r}0.0008 \\
(0.67)\end{array}$ & $\begin{array}{r}0.0007 \\
(0.58)\end{array}$ \\
\hline$\lambda_{\mathrm{LT} \_\mathrm{Rev}}$ & $\begin{array}{r}-0.0002 \\
(-0.14)\end{array}$ & $\begin{array}{r}0.0003 \\
(0.31)\end{array}$ & $\begin{array}{r}0.0005 \\
(0.51)\end{array}$ & $\begin{array}{r}0.0004 \\
(0.47)\end{array}$ & $\begin{array}{r}0.0006 \\
(0.69)\end{array}$ & $\begin{array}{r}0.0004 \\
(0.49)\end{array}$ & $\begin{array}{r}0.0003 \\
(0.31)\end{array}$ & $\begin{array}{r}0.0004 \\
(0.48)\end{array}$ & $\begin{array}{r}0.0005 \\
(0.60)\end{array}$ & $\begin{array}{r}0.0005 \\
(0.57)\end{array}$ & $\begin{array}{r}0.0009 \\
(1.08)\end{array}$ & $\begin{array}{r}0.0008 \\
(0.98)\end{array}$ & $\begin{array}{r}0.0009 \\
(1.06)\end{array}$ & $\begin{array}{r}0.0010 \\
(1.13)\end{array}$ & $\begin{array}{r}0.0009 \\
(1.06)\end{array}$ & $\begin{array}{r}0.0015 \\
(1.51)\end{array}$ \\
\hline$\lambda_{\mathrm{VIX}}$ & $\begin{array}{r}-0.0011 \\
(-1.02)\end{array}$ & $\begin{array}{r}-0.0010 \\
(-1.10)\end{array}$ & $\begin{array}{r}-0.0012 \\
(-1.44)\end{array}$ & $\begin{array}{r}-0.0004 \\
(-0.62)\end{array}$ & $\begin{array}{r}-0.0008 \\
(-1.13)\end{array}$ & $\begin{array}{r}-0.0009 \\
(-1.27)\end{array}$ & $\begin{array}{r}-0.0007 \\
(-1.10)\end{array}$ & $\begin{array}{r}-0.0005 \\
(-0.83)\end{array}$ & $\begin{array}{r}-0.0007 \\
(-1.04)\end{array}$ & $\begin{array}{r}-0.0008 \\
(-1.22)\end{array}$ & $\begin{array}{r}-0.0006 \\
(-0.94)\end{array}$ & $\begin{array}{r}-0.0005 \\
(-0.83)\end{array}$ & $\begin{array}{r}-0.0006 \\
(-0.90)\end{array}$ & $\begin{array}{r}-0.0006 \\
(-0.89)\end{array}$ & $\begin{array}{r}-0.0006 \\
(-0.94)\end{array}$ & $\begin{array}{r}-0.0006 \\
(-0.84)\end{array}$ \\
\hline$\lambda_{\mathrm{IVol}}$ & $\begin{array}{r}0.1002 \\
(1.23)\end{array}$ & $\begin{array}{r}0.0838 \\
(1.12)\end{array}$ & $\begin{array}{r}0.0381 \\
(0.53)\end{array}$ & $\begin{array}{r}0.0442 \\
(0.70)\end{array}$ & $\begin{array}{r}0.0307 \\
(0.52)\end{array}$ & $\begin{array}{r}0.0379 \\
(0.65)\end{array}$ & $\begin{array}{r}0.0190 \\
(0.32)\end{array}$ & $\begin{array}{r}0.0131 \\
(0.22)\end{array}$ & $\begin{array}{r}0.0022 \\
(0.04)\end{array}$ & $\begin{array}{r}-0.0019 \\
(-0.03)\end{array}$ & $\begin{array}{r}-0.0091 \\
(-0.15)\end{array}$ & $\begin{array}{r}-0.0153 \\
(-0.26)\end{array}$ & $\begin{array}{r}-0.0246 \\
(-0.40)\end{array}$ & $\begin{array}{r}-0.0197 \\
(-0.33)\end{array}$ & $\begin{array}{r}-0.0188 \\
(-0.31)\end{array}$ & $\begin{array}{r}-0.0617 \\
(-1.09)\end{array}$ \\
\hline \multicolumn{2}{|c|}{ Panel B: $\lambda_{\text {IVoI }}(20)-\lambda_{I V o I}(N)$} & $\begin{array}{r}0.0064 \\
(0.22) \\
\end{array}$ & $\begin{array}{r}0.0521 \\
(1.59) \\
\end{array}$ & $\begin{array}{r}0.0460 \\
(1.03) \\
\end{array}$ & $\begin{array}{r}0.0595 \\
(1.21) \\
\end{array}$ & $\begin{array}{r}0.0523 \\
(1.00) \\
\end{array}$ & $\begin{array}{r}0.0712 \\
(1.33) \\
\end{array}$ & $\begin{array}{r}0.0771 \\
(1.41) \\
\end{array}$ & $\begin{array}{r}0.0880 \\
(1.59) \\
\end{array}$ & $\begin{array}{r}0.0921 \\
(1.62) \\
\end{array}$ & $\begin{array}{r}0.0993 \\
(1.72) \\
\end{array}$ & $\begin{array}{r}0.1055 \\
(1.82) \\
\end{array}$ & $\begin{array}{r}0.1148 \\
(1.99) \\
\end{array}$ & $\begin{array}{r}0.1099 \\
(1.91) \\
\end{array}$ & $\begin{array}{r}0.1090 \\
(1.88) \\
\end{array}$ & $\begin{array}{r}0.1519 \\
(2.61) \\
\end{array}$ \\
\hline
\end{tabular}

Table 6: Pricing of idiosyncratic volatility within the Intertemporal CAPM 
The table presents averages for the prices of risk associated with idiosyncratic volatility, the market excess returns and shocks to dividend yield $(D Y)$, default spread $(D S)$, the slope of the term structure $(T S)$ and the 3-month Treasury-bill rate (TB), where the later four factors are proxies for unwelcome change in the investment opportunity set of agents over time. The prices of risk are estimated from the second-step of Fama and MacBeth (1973) regressions over the period January 1973 - December 2011. $N$ is the maximum number of stocks included in the portfolios, ALL means that the 100 Fama and French (1992) portfolios were considered in the cross-sectional regressions. $\lambda_{\text {IVol }}(20)-\lambda_{\text {IVol }}(N)$ measures the difference in the prices of idiosyncratic volatility for the portfolio with 20 stocks and the portfolio with $N$ stocks. $t$-statistics are in parentheses.

\begin{tabular}{|c|c|c|c|c|c|c|c|c|c|c|c|c|c|c|c|c|}
\hline$N<=$ & 20 & 25 & 30 & 40 & 50 & 60 & 70 & 80 & 90 & 100 & 120 & 140 & 160 & 180 & 200 & ALL \\
\hline \multicolumn{17}{|c|}{ Panel A: Estimated prices of risk } \\
\hline$\lambda_{0}$ & $\begin{array}{r}0.0034 \\
(1.35)\end{array}$ & $\begin{array}{r}0.0044 \\
(1.92)\end{array}$ & $\begin{array}{r}0.0056 \\
(2.54)\end{array}$ & $\begin{array}{r}0.0049 \\
(2.30)\end{array}$ & $\begin{array}{r}0.0047 \\
(2.19)\end{array}$ & $\begin{array}{r}0.0049 \\
(2.30)\end{array}$ & $\begin{array}{r}0.0057 \\
(2.61)\end{array}$ & $\begin{array}{r}0.0061 \\
(2.78)\end{array}$ & $\begin{array}{r}0.0061 \\
(2.80)\end{array}$ & $\begin{array}{r}0.0065 \\
(2.99)\end{array}$ & $\begin{array}{r}0.0069 \\
(3.19)\end{array}$ & $\begin{array}{r}0.0071 \\
(3.25)\end{array}$ & $\begin{array}{r}0.0073 \\
(3.33)\end{array}$ & $\begin{array}{r}0.0074 \\
(3.37)\end{array}$ & $\begin{array}{r}0.0074 \\
(3.36)\end{array}$ & $\begin{array}{r}0.0084 \\
(3.90)\end{array}$ \\
\hline$\lambda_{\mathrm{M}}$ & $\begin{array}{r}0.0008 \\
(0.44)\end{array}$ & $\begin{array}{r}0.0001 \\
(0.05)\end{array}$ & $\begin{array}{r}0.0001 \\
(0.06)\end{array}$ & $\begin{array}{r}0.0004 \\
(0.23)\end{array}$ & $\begin{array}{r}0.0003 \\
(0.21)\end{array}$ & $\begin{array}{r}0.0002 \\
(0.14)\end{array}$ & $\begin{array}{r}-0.0003 \\
(-0.21)\end{array}$ & $\begin{array}{r}-0.0008 \\
(-0.45)\end{array}$ & $\begin{array}{r}-0.0009 \\
(-0.54)\end{array}$ & $\begin{array}{r}-0.0012 \\
(-0.72)\end{array}$ & $\begin{array}{r}-0.0015 \\
(-0.88)\end{array}$ & $\begin{array}{r}-0.0018 \\
(-1.03)\end{array}$ & $\begin{array}{r}-0.0019 \\
(-1.09)\end{array}$ & $\begin{array}{r}-0.0019 \\
(-1.12)\end{array}$ & $\begin{array}{r}-0.0018 \\
(-1.09)\end{array}$ & $\begin{array}{r}-0.0024 \\
(-1.44)\end{array}$ \\
\hline$\lambda_{\text {UDY }}$ & $\begin{array}{r}-0.0001 \\
(-0.07)\end{array}$ & $\begin{array}{r}-0.0001 \\
(-0.07)\end{array}$ & $\begin{array}{r}-0.0005 \\
(-0.39)\end{array}$ & $\begin{array}{r}-0.0003 \\
(-0.25)\end{array}$ & $\begin{array}{r}-0.0001 \\
(-0.11)\end{array}$ & $\begin{array}{r}-0.0003 \\
(-0.29)\end{array}$ & $\begin{array}{r}-0.0003 \\
(-0.28)\end{array}$ & $\begin{array}{r}-0.0002 \\
(-0.19)\end{array}$ & $\begin{array}{r}-0.0002 \\
(-0.22)\end{array}$ & $\begin{array}{r}-0.0002 \\
(-0.22)\end{array}$ & $\begin{array}{r}-0.0001 \\
(-0.09)\end{array}$ & $\begin{array}{r}-0.0003 \\
(-0.27)\end{array}$ & $\begin{array}{r}-0.0002 \\
(-0.18)\end{array}$ & $\begin{array}{r}-0.0002 \\
(-0.20)\end{array}$ & $\begin{array}{r}-0.0004 \\
(-0.33)\end{array}$ & $\begin{array}{r}-0.0001 \\
(-0.12)\end{array}$ \\
\hline$\lambda_{\text {UDS }}$ & $\begin{array}{r}-0.0002 \\
(-0.12)\end{array}$ & $\begin{array}{r}-0.0004 \\
(-0.32)\end{array}$ & $\begin{array}{r}-0.0008 \\
(-0.77)\end{array}$ & $\begin{array}{r}-0.0010 \\
(-0.95)\end{array}$ & $\begin{array}{r}-0.0011 \\
(-1.10)\end{array}$ & $\begin{array}{r}-0.0010 \\
(-0.94)\end{array}$ & $\begin{array}{r}-0.0010 \\
(-0.95)\end{array}$ & $\begin{array}{r}-0.0011 \\
(-1.04)\end{array}$ & $\begin{array}{r}-0.0011 \\
(-1.12)\end{array}$ & $\begin{array}{r}-0.0013 \\
(-1.26)\end{array}$ & $\begin{array}{r}-0.0013 \\
(-1.29)\end{array}$ & $\begin{array}{r}-0.0013 \\
(-1.30)\end{array}$ & $\begin{array}{r}-0.0015 \\
(-1.44)\end{array}$ & $\begin{array}{r}-0.0015 \\
(-1.50)\end{array}$ & $\begin{array}{r}-0.0014 \\
(-1.37)\end{array}$ & $\begin{array}{r}-0.0016 \\
(-1.55)\end{array}$ \\
\hline$\lambda$ UTS & $\begin{array}{r}0.0036 \\
(2.17)\end{array}$ & $\begin{array}{r}0.0035 \\
(2.21)\end{array}$ & $\begin{array}{r}0.0028 \\
(1.91)\end{array}$ & $\begin{array}{r}0.0023 \\
(1.54)\end{array}$ & $\begin{array}{r}0.0024 \\
(1.58)\end{array}$ & $\begin{array}{r}0.0020 \\
(1.31)\end{array}$ & $\begin{array}{r}0.0022 \\
(1.49)\end{array}$ & $\begin{array}{r}0.0023 \\
(1.57)\end{array}$ & $\begin{array}{r}0.0024 \\
(1.60)\end{array}$ & $\begin{array}{r}0.0026 \\
(1.68)\end{array}$ & $\begin{array}{r}0.0025 \\
(1.68)\end{array}$ & $\begin{array}{r}0.0024 \\
(1.61)\end{array}$ & $\begin{array}{r}0.0022 \\
(1.44)\end{array}$ & $\begin{array}{r}0.0023 \\
(1.48)\end{array}$ & $\begin{array}{r}0.0024 \\
(1.62)\end{array}$ & $\begin{array}{r}0.0025 \\
(1.50)\end{array}$ \\
\hline$\lambda_{\text {UTB }}$ & $\begin{array}{r}-0.0016 \\
(-1.21)\end{array}$ & $\begin{array}{r}-0.0015 \\
(-1.19)\end{array}$ & $\begin{array}{r}-0.0011 \\
(-0.93)\end{array}$ & $\begin{array}{r}-0.0006 \\
(-0.51)\end{array}$ & $\begin{array}{r}-0.0010 \\
(-0.82)\end{array}$ & $\begin{array}{r}-0.0010 \\
(-0.80)\end{array}$ & $\begin{array}{r}-0.0011 \\
(-0.91)\end{array}$ & $\begin{array}{r}-0.0013 \\
(-1.06)\end{array}$ & $\begin{array}{r}-0.0012 \\
(-0.96)\end{array}$ & $\begin{array}{r}-0.0013 \\
(-1.06)\end{array}$ & $\begin{array}{r}-0.0012 \\
(-1.01)\end{array}$ & $\begin{array}{r}-0.0011 \\
(-0.93)\end{array}$ & $\begin{array}{r}-0.0009 \\
(-0.78)\end{array}$ & $\begin{array}{r}-0.0010 \\
(-0.80)\end{array}$ & $\begin{array}{r}-0.0013 \\
(-1.08)\end{array}$ & $\begin{array}{r}-0.0013 \\
(-1.07)\end{array}$ \\
\hline$\lambda_{\text {IVol }}$ & $\begin{array}{r}0.0937 \\
(1.88)\end{array}$ & $\begin{array}{r}0.0735 \\
(1.62)\end{array}$ & $\begin{array}{r}0.0282 \\
(0.67)\end{array}$ & $\begin{array}{r}0.0520 \\
(1.31)\end{array}$ & $\begin{array}{r}0.0583 \\
(1.53)\end{array}$ & $\begin{array}{r}0.0548 \\
(1.40)\end{array}$ & $\begin{array}{r}0.0393 \\
(1.00)\end{array}$ & $\begin{array}{r}0.0390 \\
(1.00)\end{array}$ & $\begin{array}{r}0.0419 \\
(1.05)\end{array}$ & $\begin{array}{r}0.0389 \\
(0.98)\end{array}$ & $\begin{array}{r}0.0336 \\
(0.85)\end{array}$ & $\begin{array}{r}0.0341 \\
(0.85)\end{array}$ & $\begin{array}{r}0.0315 \\
(0.78)\end{array}$ & $\begin{array}{r}0.0302 \\
(0.76)\end{array}$ & $\begin{array}{r}0.0274 \\
(0.68)\end{array}$ & $\begin{array}{r}0.0051 \\
(0.12)\end{array}$ \\
\hline \multicolumn{2}{|c|}{ Panel B: $\lambda_{\text {IVoI }}(20)-\lambda_{\text {IVol }}(N)$} & $\begin{array}{r}0.0181 \\
(1.07) \\
\end{array}$ & $\begin{array}{r}0.0634 \\
(2.87) \\
\end{array}$ & $\begin{array}{r}0.0395 \\
(1.34) \\
\end{array}$ & $\begin{array}{r}0.0332 \\
(1.01) \\
\end{array}$ & $\begin{array}{r}0.0368 \\
(1.09) \\
\end{array}$ & $\begin{array}{r}0.0522 \\
(1.53) \\
\end{array}$ & $\begin{array}{r}0.0526 \\
(1.51) \\
\end{array}$ & $\begin{array}{r}0.0497 \\
(1.39) \\
\end{array}$ & $\begin{array}{r}0.0527 \\
(1.48) \\
\end{array}$ & $\begin{array}{r}0.0580 \\
(1.61) \\
\end{array}$ & $\begin{array}{r}0.0575 \\
(1.57) \\
\end{array}$ & $\begin{array}{r}0.0601 \\
(1.63) \\
\end{array}$ & $\begin{array}{r}0.0614 \\
(1.67) \\
\end{array}$ & $\begin{array}{r}0.0642 \\
(1.73) \\
\end{array}$ & $\begin{array}{r}0.0865 \\
(2.15) \\
\end{array}$ \\
\hline
\end{tabular}

